\title{
Technologie indicators: population, labour and schooling : 1990 report
}

Citation for published version (APA):

van Dam, J. W., \& de Grip, A. (1990). Technologie indicators: population, labour and schooling : 1990 report. Researchcentrum voor Onderwijs en Arbeidsmarkt, Faculteit der Economische Wetenschappen. ROA Reports No. 5E https://doi.org/10.26481/umarep.199005E

Document status and date:

Published: 01/01/1990

DOI:

10.26481/umarep.199005E

Document Version:

Publisher's PDF, also known as Version of record

\section{Please check the document version of this publication:}

- A submitted manuscript is the version of the article upon submission and before peer-review. There can be important differences between the submitted version and the official published version of record.

People interested in the research are advised to contact the author for the final version of the publication, or visit the DOI to the publisher's website.

- The final author version and the galley proof are versions of the publication after peer review.

- The final published version features the final layout of the paper including the volume, issue and page numbers.

Link to publication

\footnotetext{
General rights rights.

- You may freely distribute the URL identifying the publication in the public portal. please follow below link for the End User Agreement:

www.umlib.nl/taverne-license

Take down policy

If you believe that this document breaches copyright please contact us at:

repository@maastrichtuniversity.nl

providing details and we will investigate your claim.
}

Copyright and moral rights for the publications made accessible in the public portal are retained by the authors and/or other copyright owners and it is a condition of accessing publications that users recognise and abide by the legal requirements associated with these

- Users may download and print one copy of any publication from the public portal for the purpose of private study or research.

- You may not further distribute the material or use it for any profit-making activity or commercial gain

If the publication is distributed under the terms of Article $25 \mathrm{fa}$ of the Dutch Copyright Act, indicated by the "Taverne" license above, 
TECHNOLOGY INDICATORS: POPULATION, LABOUR AND SCHOOLING

- 1990 Report -

ROA-R-1990/5E

J.W. van Dam

A. de Grip

RESEARCH CENTRE FOR EDUCATION AND LABOUR MARKET

Faculty of Economic Sciences

Rijksuniversiteit Limburg

Maastricht, November 1990 


\section{CIP-GEGEVENS KONINKLIJKE BIBLIOTHEEK, DEN HAAG}

Dam, J.W. van

Technology indicators: population, labour and schooling: 1990 report / J.W. van Dam, A. de Grip; [transl. from the Dutch]. - Maastricht: Research Centre for Education and Labour Market, Faculty of Economic Sciences, Rijksuniversiteit Limburg. - III., fig., tab. - (Report / Research Centre for Education and Labour Market, ISSN 0922-8098; 1990/5E).

Vert. van: Technologie-inidcatoren: bevolking, arbeid en scholing: rapportage 1990. Maastricht: Researchcentrum voor Onderwijs en Arbeidsmarkt, Faculteit der Economische Wetenschappen, Rijksuniversiteit Limburg, 1990. - (Rapport / Researchcentrum voor Onderwijs en Arbeidsmarkt ISSN 0922-8098; 1990/5). - met lit. opg.

ISBN 90-5321-048-2.

Trefw.: onderwijs en arbeidsmarkt; Nederland. 


\section{CONTENTS}

page

TABLES AND FIGURES

ACKNOWLEDGEMENT

1. INTRODUCTION

2. KEY INDICATORS UPDATED 4

2.1. Initial education 4

2.1.1. Dual education 4

2.1.2. Share of vocational education in total regular education 5

2.2. Labour force and schoolleavers 6

2.2.1. Share of technically skilled persons in the total number of $\begin{array}{ll}\text { schoolleavers and in the labour force } & 6\end{array}$

2.3. The need for training $\quad 7$

2.3.1. Labour-market situation for the technically educated: tension indicators 7

2.3.2. Age composition of the (active) population 9

2.4. Educational efforts 13

2.4.1. Proportion of the potential labour force in post-elementary education 13

3. INVENTARISATION AND DESCRIPTION OF COMPLEMENTARY DATA 15

3.1. Formulation of questions; method 15

3.2. Completion of existing key indicators 16

3.3. Demographic developments 18

3.4. Labour-market data 22

3.4.1. Bottlenecks on the labour market 22

3.4.2. Labour force by level of education 26

3.5. Educational data 30

3.5.1. Participation in higher education 30

3.5.2. Average level of education 31

3.5.3. Premature schoolleavers 31

3.5.4. Education and training of young people 32

3.5.5. Quality of education 33

3.5.6. Computers in education 34

3.5.7. Expenditure on education 36

3.6. Information on training 37

3.7. Mobilisation of R\&D potential 38 
4. INTERNATIONAL DEVELOPMENTS

LITERATURE

CONSULTED AUTHORITIES 


\section{TABLES AND FIGURES}

Key indicators:

Table 1 : Proportion of dual-system students in total population between the ages of 15 and 24.

Table 2 : Indicator of the share of vocational education (second and third levels).

Table 3 : Share of technically trained (school leavers and labour force).

Table 4 : Unemployment rates among schoolleavers (May figures).

Table 5 : Percentage shares of age groups in total population.

Table 6 : Percentage shares of age groups in active population.

Table 7A: Percentage shares of age groups in total population. (Forecasts for the Netherlands).

Table 7B: Percentage shares of age groups in potential labour force. (Forecast for the Netherlands.)

Table 8 : Participation in schooling of the potential labour force between the ages of 15 and 49 (in the wide sense).

Table 9 : Participation in schooling of the potential labour force between the ages of 15 and 49 (in the narrow sense).

Demographic developments:

Table 10: Forecasts of the median age of the labour force in 1980, 2010 en 2025 (in years).

Table 11: Forecasts of the median age by sector (in years).

Table 12: Forecasts of the median age by occupational class (in years).

Table 13: Development of the number of 16-18-year-olds, from 1968 to $2000(1970=100)$.

Labour-market data:

Table 14: Standardised unemployment, in percentages of the labour force.

Table 15: Proportion of companies short of expert labour.

Table 16: Unemployment rate among 15-24-year-olds.

Table 17: Unemployment by level of education, age and sex, 1988, in percentages.

Table 18: Ratio between unemployment rates of persons of level-A education and leveleducation.

Table 19: Proportion of active population with level-A education, by sector, in percentages.

Table 20: Proportion of active population with level-E education, by sector, in percentages.

Table 21: Annual percentage changes in the proportion of active population with level-A education.

Table 22: Annual percentage changes in the proportion of active population with level-E education.

Table 23: Annual changes of the shares of education levels in the potential labour force.

Table 24: Forecasts of employment for technicians and total employment, by level of educati- 
on, $1982 / 8-2000$.

Educational data:

Table 25: Participation in higher education as a percentage of the number of persons between the ages of 20 and 24.

Table 26: Average level of education of potential labour force, 1988.

Table 27: Premature schoolleavers as a percentage of the total number of schoolleavers.

Table 28: Participation of 18-year-olds in education and training, 1986, in percentages.

Table 29: Average score of 13-year-old students in international comparative mathematics examination, 1982.

Table 30: Ranking of countries by learning performances of students in physical sciences, by age brackets, 1986.

Table 31: Median number of computers used in secondary schools with computers, 1989.

Table 32: Subject areas in which computers are used most, in percentages.

Training activities:

Table 33: Government expenditure on education in percentages of GNP.

Table 34: Participation in training activities, by occupational classes, 1987-88, in percentages.

Table 35: Sources for the financing of training activities, in percentages.

Table 36: R\&D-staff related to the scientific and technical (S\&C) potential.

Figures:

Figure 1: Population and labour force of the EC, changes between 1987 and 2000, in percentages.

Figure 2: Development of the share of $16-18$-year-olds, index figures $(1970=100)$. 


\section{ACKNOWLEDGEMENT}

This study was commissioned by the Dutch Ministry of Economic Affairs, Directorate for General Technology Policy. It has been carried out by Drs J.W. van Dam and Dr A. de Grip (project leader), assisted by G. Janssen and P. Ghijsen.

It was the second study carried out by the ROA towards the development of a databank for technology policy, 'METING'. The first was performed in 1989 by $\operatorname{Dr}$ A. de Grip and Mrs Drs W.J. Nusselder, and described in the ROA-report 'Technologie-indicatoren met betrekking tot scholing en arbeid' (ROA-R-1989/4), also published in English (ROA-R-1989/4E).

The report now lying before you is a follow-up to the previous one. It consists of two parts. The first part is a description of the updating of six key indicators developed in 1989, followed by a brief interpretation (see chapter 2). The second part is an inventory of figures on population, labour and training that may be relevant to technology policy (see chapter 3 ). The inventory does no more than establish the situation of one particular moment in time, a fact to be kept in mind because lately, various initiatives have been taken towards internationally comparable data on education, training and labour market. The two parts are introduced in chapter 1, and rounded off by a short evaluation and some recommendations in chapter 4 . 


\section{INTRODUCTION}

The report METING 1, Indicatoren voor de technologische positiebepaling van Nederland (Ministry of Economic Affairs, 1989) explained the organisation and objectives of 'METING' ('MEASUREMENT'), a new databank for indicators of technology, featuring the six categories of indicators. One category refers to the technological potential of the labour force as an indication of the breeding ground for technological development. The METING databank is still at the stage of development. Last year, the Research Centre for Education and Labour Market (ROA) was requested to make an inventory of the availability of internationally comparable indicators of labour and training (see De Grip and Nusselder, 1989).

Given the evaluation of last year's inventory, this year's decision was to focus on six selected 'key indicators': relative participation in dual education, the share of vocational education in total regular education, the share of technically skilled people in the total number of schoolleavers and in the labour force, the labour-market situation for the technically skilled, the age composition of the (economically active) population, and the portion of the labour force enrolled in training courses. This year's study consists of two parts. The first part concerns the updating of the key indicators of the societal breeding ground for technological innovations, mostly on the basis of international statistical data sources of ILO, UNESCO, Eurostat, and OECD. The second part presents the results of an exploration carried out among foreign statistical offices and such in search of data on population, labour and training, with a view to completing the existing and developing new indicators. The exploration focused on a selection of industrialised countries: the Netherlands, (West) Germany, France, the United Kingdom, Sweden, the United States, and Japan. Letters were addressed to some 60 statistical offices, research institutes and/or researchers from these countries, asking them for data or research reports.

The relation between technological development on the one hand and education and labour on the other is one of mutual influence. For one thing, the training of the labour force is an important determinant of a country's Research \& Development capacity. The degree of skill of the labour force thus influences the innovative capacity of the society. On the other hand, technological progress has a tremendous impact on contemporary society. It affects not only the growth of the national economy and the shifts in the economic structure, but also the volume and composition of employment, the contents of functions, the demand for certain skills, and hence the nature and level of the training required. Technological progress is momentous now only because of the kind of changes it entails, but also because its pace creates uncertainty and thus takes a heavy toll from individuals as well as society as a whole. In that sense, the degree of skill the labour force possesses is an important determinant of the 
diffusion potential of technological progress. Indeed, an improved production technique alone is no guarantee of higher productivity. Certain marginal conditions have to be satisfied, for one thing in the matter of staff training1.

The relevance of the labour force's skill for the society's innovation potential and the uncertainty due to technological innovations as well as their effects on many facets of life, make the success of labour-market policy conditional on a good insight into changes and their consequences. To make optimum use of the available societal and scientific breeding ground for technological advance is essential. As already pointed out, the nature and the level of skill of the (active) population are a determinant of, as well as a significant marginal condition for, technological innovation. Besides, an adequately skilled management is required to point the way to new technological opportunities. The speed of technological advance tends to make all knowledge and skill soon obsolete, so that permanent training is becoming increasingly important.

The METING memorandum referred to above, proposes a classification of indicators similar to that of the Indicator Bank of the Science and Technology Agency in Japan (Kodama and Niwa, 1987). This classification distinguishes six types of indicators:

1. Indicators that can be considered to belong to the societal breeding ground for technological advance.

2. Indicators that can be considered to belong to the scientific and technological breeding ground and are indicative of the Research and Development (R\&D) activities performed.

3. Indicators that can be considered to belong to the R\&D infrastructure and serve to try and measure R\&D activities.

4. Indicators indicative of $R \& D$ results.

5. Indicators serving to measure the economic effects of R\&D.

6. Indicators representing the indirect effects of science and technology on society and their acceptation by society.

Indicators referring to education, training, and labour can be considered criteria of, in particular, the scientific and technological breeding ground. Strikingly, the Science and Technology Agency presents the societal (sub 1) and the scientific and technological breeding grounds (sub 2) solely as factors relevant to the generation of $R \& D$ activities, leaving out of consideration how far they may be indicative of the diffusion of technological progress. In the present report we try to give due attention to both the innovation and the diffusion potential.

1. By training we understand not only initial training but also the retraining of employed persons, job seekers, and others no longer being educated at regular day schools. 
According the METING memorandum, any indicators to be proposed should satisfy the following conditions. They should be relevant to the various aspects of General Technology Policy as well as practicable. Input and output indicators should balance each other more or less. Some indicators should give an insight into the societal aspects of technological advance. For the sake of international comparison, indicators should be feasible for other countries as well. And finally, the data sources underlying the indicators should guarantee some degree of contiuity. Especially the conditions of international comparability and continuity have drawn full attention from the writers of this year's as well as last year's report.

Chapter 2 presents the updated key indicators. The classification is the same as last year's. Section 2.1 discusses two indicators of the contribution of initial education to the future breeding ground for technological advance. The indicator presented in Section 2.2 measures how far the contemporary (potential) labour force functions as a breeding ground of technological advance. Similar indicators for schoolleavers serve to measure the dynamics of the breeding ground for technological progress. Section 2.3 presents two indicators measuring the necessity of training to overcome present or possible future impediments to the further diffusion of technological progress. Finally, in section 2.4 there appears an indicator of the present training efforts made in response to such impediments. Chapter 3 displays the results of the investigation to establish the availability of data concerning population, labour and training in a selection of industrialised countries. A brief evaluation and some recommendations complete the report. The annex lists the agencies with which we have got in touch. 


\section{KEY INDICATORS UPDATED}

\subsection{Initial education}

\subsubsection{Dual education}

Dual education is the collective name for types of education that combine learning and working, thus providing the students with basic skills for their future careers. In the Netherlands, most dual education takes the form of apprenticeship. The participation of young people in dual education, as already pointed out in De Grip and Nusselder (1989), can be considered indicative of the scientific and technological breeding ground for, in particular, the diffusion of technological advance.

The number of students in dual education can be calculated from the results of the Labour Force Survey (1983-1988) of the European Community. In that survey, persons between the ages of 15 and 50 were asked to state the type and purpose of any training course 2 they had been engaged in during four weeks preceding the survey. This time, unlike last year, we related the number of persons participating in dual education to ILO-figures of the total number of persons in the 15-24 age bracket. This makes a comparison among countries possible.

The data of table 1 may be slightly distorted by shifts in the non-response of the survey, and should therefore be interpreted with some caution. Nevertheless the fact transpires clearly that dual education is much more important in Denmark and (West) Germany, at about 24 and 18 per cent in 1988, respectively, than in the other countries investigated. The Netherlands are clearly in the lower regions after the striking drop in the percentage in 1988. In Belgium and the United Kingdom, the tendency was declining all through the 1983-88 period, though a slight recovery was recorded in the United Kingdom in 1988. By contrast, in Denmark and (West) Germany, dual education seems to have made real headway in the 1980s. Because we could not trace corresponding figures from other international data sources about Japan, Sweden and the United States of America, for the time being this indicator is only available for the EC countries.

2. This survey makes a distinction between "apprenticeship" (learning contract) and other types of dual education. 
Table 1. Proportion of dual-system students in total population between the ages of 15 and 24

\begin{tabular}{|c|c|c|c|c|c|c|}
\hline & $\begin{array}{c}1983 \\
\% \\
\end{array}$ & $\begin{array}{c}1984 \\
\% \\
\end{array}$ & $\begin{array}{c}1985 \\
\% \\
\end{array}$ & $\begin{array}{c}1986 \\
\%\end{array}$ & $\begin{array}{c}1987 \\
\%\end{array}$ & $\begin{array}{c}1988 \\
\%\end{array}$ \\
\hline The Netherlands & 2.5 & 2.4 & 2.3 & 2.3 & 2.3 & 1.9 \\
\hline France & 2.6 & 2.6 & 2.5 & 2.4 & 2.6 & 2.8 \\
\hline (West) Germany & 10.0 & 13.5 & 15.5 & 17.7 & 17.4 & 17.7 \\
\hline United Kingdom & 7.6 & 5.0 & 5.6 & 4.8 & 4.9 & 5.3 \\
\hline Italy & 0.5 & 0.6 & 0.5 & 0.6 & 0.6 & 0.6 \\
\hline Belgium & 2.3 & 1.9 & 1.8 & 1.9 & 1.6 & 1.3 \\
\hline Luxemburg & 5.8 & 6.3 & 7.0 & 6.1 & 5.7 & 5.1 \\
\hline Ireland & 2.8 & 2.2 & 2.5 & 2.0 & 1.9 & -- \\
\hline Denmark & 7.4 & 18.8 & 22.1 & 22.7 & 23.7 & 23.8 \\
\hline Greece & 0.3 & 0.3 & 0.4 & 0.5 & 0.3 & 0.3 \\
\hline
\end{tabular}

Source: Eurostat/ILO/ROA

\subsubsection{Share of vocational education in total regular education}

This sub-section's indicator represents the share of vocational students (second and third levels3) in the total number of second- and third-level students. On the basis of the Statistical Yearbook of Unesco (1983-1987) a division into vocational and general education is possible. To compose the indicator we have counted all third-level education (Higher Education) as vocational education.

The vocational/general ratio indicates in particular the degree to which people in their later careers are open to technological advance. The underlying assumption is that workers with a broad initial vocational education tend to be more responsive to innovations than workers who have gained their skill in practice; the latter tend in particular to fall short on theoretical knowledge. Therefore, this indicator can be considered representative of the scientific and technological breeding ground for the diffusion of technological change. Possibly a higher share of vocational education can also be considered to add to the society's innovative potential.

Table 2 shows that the Netherlands and Sweden have a high proportion of students in vocational education, whereas in the United Kingdom it is low. In most countries this indicator shows a rising tendency, but in Japan it is declining steadily. For all European countries except Sweden the increase in the number of vocational students continued in 1986; it was particularly large in (West) Germany and Austria.

3. The second and third levels comprise all education beyond the elementary stage. 
Table 2. Indicator of the share of vocational education (second and third levels)

\begin{tabular}{lcccccccc}
\hline & $\begin{array}{c}1975 \\
\%\end{array}$ & $\begin{array}{c}1980 \\
\%\end{array}$ & $\begin{array}{c}1981 \\
\%\end{array}$ & $\begin{array}{c}1982 \\
\%\end{array}$ & $\begin{array}{c}1983 \\
\%\end{array}$ & $\begin{array}{c}1984 \\
\%\end{array}$ & $\begin{array}{c}1985 \\
\%\end{array}$ & $\begin{array}{c}1986 \\
\%\end{array}$ \\
\hline The Netherlands & 51 & 53 & 53 & 54 & 55 & 55 & 56 & 57 \\
United States & -- & -- & -- & -- & -- & -- & -- & -- \\
Japan & 34 & 32 & 32 & 30 & 30 & 29 & 28 & 28 \\
France & 35 & 36 & 36 & 40 & 38 & 39 & 36 & 40 \\
(West) Germany & 32 & 33 & 35 & 37 & 29 & 31 & 32 & 48 \\
United Kingdom & 16 & 18 & 19 & 19 & 20 & 23 & 24 & 26 \\
Sweden & 45 & 45 & 46 & 49 & 51 & 51 & -- & 50 \\
Austria & 25 & 33 & 33 & 35 & 37 & 40 & 41 & 54 \\
\hline
\end{tabular}

Source: UNESCO $(1984,1985,1986,1987)$

Legend: -- = not available

\subsection{Labour force and schoolleavers}

2.2.1. Share of technically skilled persons in the total number of schoolleavers and in the labour force

This section presents (sub-)indicators of the shares of technically schooled persons in the most recent group of schoolleavers and in the labour force. A similar indicator relates the proportion of technically educated schoolleavers to that of the potential labour force. The (sub)indicator of the share of technically educated persons in the potential labour force measures the scientific and technological breeding ground of society, in terms of innovation as well as diffusion. The (sub)indicator referring to schoolleavers and especially that relating the proportions of technically educated among schoolleavers and the potential labour force (column 3 of the table) are the more dynamic measures of the evolution of this breeding ground.

We have used the information of the Skill 1990-model to update last year's forecasts, applying a slightly different method of calculation. We were unable to apply this method to last year's figures because the Dutch Central Planning Bureau had included agriculturally schooled persons in the 'technically educated' labour force. As a consequence, this year's data diverge from last year's, and the interpreted indicator is higher across the board than the one calculated last year; however, the development is expected to move in the same direction. A striking feature is that after 1986/87 the indicator has dropped to below one hundred. It means that, ceteris paribus, the inflow of schoolleavers was reducing the share of the technically educated in the potential labour force. That a similar drop does not show up for the 1990 s is due to the fact that the share of technically educated in the outflow from the potential labour force is also below average. From the (sub)indicator of the first column, the share of technically educated in the 
year classes of schoolleavers appears to be declining in the 1990 s.

Table 3. Share of technically trained (school leavers and labour force)

\begin{tabular}{lccc}
\hline & School leavers & Labour force & \multicolumn{2}{c}{ Indicator } \\
& $\%$ & $2)$ & \% \\
& $\%$ & 20.8 & 105 \\
\hline $1982 / 1983$ & 21.8 & 21.0 & 105 \\
$1983 / 1984$ & 22.1 & 21.3 & 104 \\
$1984 / 1985$ & 22.1 & 21.6 & 101 \\
$1985 / 1986$ & 21.8 & 21.8 & 100 \\
$1986 / 1987$ & 21.7 & 22.0 & 96 \\
$1987 / 1988$ & 21.2 & 22.2 & 92 \\
$1988 / 1989$ & 20.3 & 22.3 & 92 \\
$1989 / 1990$ & 20.4 & 22.4 & 88 \\
$1990 / 1991$ & 19.8 & 22.5 & 88 \\
$1991 / 1992$ & 19.9 & 22.6 & 89 \\
$1992 / 1993$ & 20.1 & 22.7 & 89 \\
$1993 / 1994$ & 20.2 & 22.8 & 89 \\
$1994 / 1995$ & 20.2 & 22.9 & 88 \\
$1995 / 1996$ & 20.1 & 22.9 & 87 \\
$1996 / 1997$ & 20.0 & 23.0 & 85 \\
$2000 / 2001$ & 19.6 & & 89 \\
\hline
\end{tabular}

Source: $C P B / R O A$

1) Share of technically trained in the cohort of schoolleavers.

2) Share of technically trained in the labour force labour force.

\subsection{The need for training}

2.3.1. Labour-market situation for the technically educated: tension indicators

Van Paridon has developed an indicator of bottlenecks on the labour market for technically educated persons representing the proportion of schoolleavers of the most recent cohort who are still unemployed (see De Grip and Heijke, 1988). It relies on unemployment figures of the District Labour Exchanges, corrected for "file corruption"4. The indicator thus obtained is, as said before, a criterion by which to identify obstacles to the diffusion of technological advance in certain segments of the labour market.

4. Following Van Paridon we assume that the file corruption among schoolleavers is great $(60$ per cent), because many remain on the registers while working in temporary jobs, whether or not acquired through an employment agency. 
$-8-$

Table 4. Unemployment rates among schoolleavers (May figures)

\begin{tabular}{|c|c|c|c|c|c|}
\hline & 1986 & 1987 & 1988 & 1989 & 1990 \\
\hline Lower Vocational Education & 19 & 15 & 15 & 14 & 13 \\
\hline - Lower technical Schools & 13 & 10 & 10 & 10 & 8 \\
\hline Intermediate Vocational Education & 9 & 8 & 10 & 10 & 7 \\
\hline - Intermediate Technical School & 5 & 4 & 4 & 5 & 3 \\
\hline Mechanical engineering & 4 & 3 & 4 & 4 & 2 \\
\hline Energy technics & 2 & 2 & 3 & 3 & 3 \\
\hline \multirow[t]{2}{*}{ Electronics } & 6 & 5 & 6 & 7 & 3 \\
\hline & 4 & 5 & 8 & 8 & 5 \\
\hline Higher Vocational Education & 12 & 10 & 12 & 11 & 9 \\
\hline - Higher Technical Schools & 4 & 4 & 5 & 5 & 4 \\
\hline Electrotechnics & 3 & 2 & 6 & 8 & 6 \\
\hline Informatics & 2 & 3 & 3 & 6 & 5 \\
\hline Mechanical engineering & 2 & 2 & 4 & 4 & 2 \\
\hline Management & 2 & 4 & 4 & 3 & 4 \\
\hline Academic Sciences & 11 & 10 & 9 & 12 & 7 \\
\hline - Technical Sciences & 6 & 5 & 5 & 6 & 4 \\
\hline Electrotechnics & 3 & 1 & 4 & 5 & 3 \\
\hline Mathematics & 3 & 4 & 6 & 6 & 3 \\
\hline Informatics & -- & 3 & 2 & 3 & 4 \\
\hline Management & 7 & 2 & 3 & 3 & 7 \\
\hline Total & 14 & 11 & 12 & 12 & 11 \\
\hline
\end{tabular}

Source: Van Paridon/ROA

Table 4 visualises the employment situation in the years between 1986 and 1990. From the table, in a tightening but still relatively easy general labour market, the situation remained relatively tight on the segment for those with a secondary or higher technical education. That points to an improvement of the labour-market position of those with a non-technical schooling. Another striking fact is that unemployment among university graduates has not deteriorated further in 1990, whereas that among university-educated information scientists does show a tendency to increase. The situation is even more gloomy for higher-educated business scientists, in particular those with a university degree.

Regrettably, no internationally comparable data could be traced in any publications of international organisations or national statistic bureaus. 


\subsubsection{Age composition of the (active) population}

Two new indicators have been evolved to represent the age composition of, respectively, total population and the economically active population (labour force) 5 . These indicators measure the declining share of the young and the increasing share of the aged in, respectively, the total and the economically active population. To comply with the wishes of the Ministry of Economic Affairs, we will give an overall picture of the age composition of the (active) population rather than specific indicators of either share.

The share of 'senior citizens' in the active population can be considered a measure of the need for training on the assumption that, as technological progress renders the labour force's initial training obsolete, retraining becomes necessary to the productive re-employment of the workers involved. In other words: the indicator measures the "vulnerability" of the labour force to technological progress. It is also a measure of the "intra-generational mobility6" required to overcome any shifts which technological advance should cause in the occupational structure. The drop in the proportion of young people (15-24) in the active and overall population indicates the society's ability to respond to the changed educational requirements due to technological progress by adjusting initial education to practical demands. Indeed, the adjustment of initial education to the developments on the labour market will have less effect as the proportion of young people in the labour force is lower.

Table 5 reviews the shares of the four age groups distinguished in total population. From this table, the drop in the share of young people is especially manifest in Sweden. Austria, France and the United Kingdom are marked by a relatively large group of over-50s. In Japan, on the other hand, the fastest increase in the older age groups occurred in the 1980 s.

5. The ILO defines the economically active population as all persons providing the supply of labour for the production of goods and services. Both employed and unemployed persons belong to the active population (ILO, 1989). Students, retired persons and women not participating in the labour market, on the contrary, do not come under the definition.

6. A. de Grip, Onderwijs en Arbeidsmarkt: Scholingsdiscrepanties, Amsterdam, 1987. 
$-10-$

Table 5. Percentage shares of age groups in total population

\begin{tabular}{|c|c|c|c|c|c|c|c|c|c|}
\hline & age & $\begin{array}{c}1980 \\
\% \\
\end{array}$ & $\begin{array}{c}1981 \\
\% \\
\end{array}$ & $\begin{array}{c}1982 \\
\% \\
\end{array}$ & $\begin{array}{c}1983 \\
\% \\
\end{array}$ & $\begin{array}{c}1984 \\
\% \\
\end{array}$ & $\begin{array}{c}1985 \\
\% \\
\end{array}$ & $\begin{array}{c}1986 \\
\% \\
\end{array}$ & $\begin{array}{c}1987 \\
\% \\
\end{array}$ \\
\hline \multirow[t]{4}{*}{ The Netherlands } & $15-24$ & 17.3 & 17.4 & 17.4 & 17.3 & 17.3 & -- & 17.2 & 16.9 \\
\hline & $25-49$ & 34.2 & 34.5 & 35.2 & 35.2 & 35.1 & -- & 36.5 & 37.2 \\
\hline & $50-65$ & 14.4 & 14.5 & 14.5 & 14.6 & 14.6 & -- & 14.7 & 14.7 \\
\hline & $65+-$ & 11.5 & 11.6 & 11.7 & 11.7 & 11.7 & -- & 12.2 & 12.5 \\
\hline \multirow[t]{4}{*}{ United States } & $15-24$ & 16.9 & 17.3 & 19.5 & -- & 17.0 & 16.6 & 16.2 & 15.7 \\
\hline & $25-49$ & 32.4 & 33.2 & 33.9 & -- & 35.1 & 35.8 & 36.4 & 37.0 \\
\hline & $50-65$ & 14.7 & 14.6 & 14.4 & -- & 14.1 & 13.9 & 13.7 & 13.5 \\
\hline & $65+-$ & 11.2 & 11.4 & 11.6 & -- & 11.9 & 11.9 & 12.1 & 12.3 \\
\hline \multirow[t]{4}{*}{ Japan } & $15-24$ & 13.8 & 13.6 & 13.7 & 13.8 & 14.0 & 14.2 & 14.4 & 14.7 \\
\hline & $25-49$ & 38.9 & 38.6 & 38.2 & 37.8 & 37.6 & 37.2 & 36.9 & 36.5 \\
\hline & $50-65$ & 14.7 & 15.1 & 15.5 & 16.0 & 16.4 & 16.8 & 17.2 & 17.5 \\
\hline & $65+-$ & 9.1 & 9.3 & 9.5 & 9.7 & 9.9 & 10.2 & 10.5 & 10.8 \\
\hline \multirow[t]{4}{*}{ France } & $15-24$ & 15.9 & 15.8 & 15.7 & 15.6 & 15.6 & 15.6 & 15.5 & 15.1 \\
\hline & $25-49$ & 33.3 & 33.4 & 33.5 & 33.7 & 33.3 & 34.1 & 34.4 & 35.0 \\
\hline & $50-65$ & 15.3 & 15.8 & 16.2 & 16.6 & 16.7 & 16.5 & 16.4 & 16.4 \\
\hline & $65+-$ & 14.5 & 14.2 & 13.9 & 13.7 & 13.4 & 13.7 & 13.9 & 13.8 \\
\hline \multirow[t]{4}{*}{ (West) Germany } & $15-24$ & 15.6 & 16.1 & 16.3 & 16.7 & 16.7 & 16.5 & 16.3 & -- \\
\hline & $25-49$ & 34.1 & 34.2 & 34.4 & 35.3 & 35.2 & 35.2 & 35.4 & -- \\
\hline & $50-65$ & 16.2 & 16.6 & 17.1 & 17.3 & 18.1 & 18.4 & 18.4 & -- \\
\hline & $65+-$ & 15.9 & 15.6 & 15.4 & 14.2 & 15.0 & 15.2 & 15.4 & -- \\
\hline \multirow[t]{4}{*}{ United Kingdom } & $15-24$ & - & 15.8 & -- & -- & - & - & 16.3 & -- \\
\hline & $25-49$ & -- & 31.8 & -- & -- & -- & -- & 33.2 & -- \\
\hline & $50-65$ & -- & 16.8 & -- & - & -- & -- & 16.2 & -- \\
\hline & $65+-$ & -- & 14.8 & -- & -- & -- & -- & 15.3 & -- \\
\hline \multirow[t]{4}{*}{ Sweden } & $15-24$ & 12.0 & -- & 12.3 & 12.5 & 12.6 & 12.6 & 12.6 & 12.7 \\
\hline & $25-49$ & 33.4 & -- & 33.7 & 34.0 & 34.2 & 34.4 & 34.3 & 34.8 \\
\hline & $50-65$ & 17.3 & - & 17.0 & 16.8 & 16.6 & 16.3 & 16.2 & 15.7 \\
\hline & $65+-$ & 16.6 & -- & 10.0 & 9.9 & 9.9 & 10.0 & -- & -- \\
\hline \multirow[t]{4}{*}{ Austria } & $15-24$ & 14.4 & 16.7 & 16.7 & 16.6 & 17.0 & 16.9 & 16.7 & 16.3 \\
\hline & $25-49$ & 34.0 & 32.3 & 32.6 & 33.3 & 33.5 & 34.0 & 34.6 & 35.3 \\
\hline & $50-65$ & 15.6 & 15.8 & 16.2 & 16.5 & 16.7 & 16.6 & 16.3 & 16.0 \\
\hline & $65+-$ & 15.5 & 15.2 & 14.9 & 14.4 & 14.3 & 14.4 & 14.5 & 14.7 \\
\hline
\end{tabular}


$-11-$

Table 6. Percentage shares of age groups in active population

\begin{tabular}{|c|c|c|c|c|c|c|c|c|c|}
\hline & age & $\begin{array}{c}1980 \\
\%\end{array}$ & $\begin{array}{c}1981 \\
\%\end{array}$ & $\begin{array}{c}1982 \\
\%\end{array}$ & $\begin{array}{c}1983 \\
\%\end{array}$ & $\begin{array}{c}1984 \\
\%\end{array}$ & $\begin{array}{c}1985 \\
\%\end{array}$ & $\begin{array}{c}1986 \\
\%\end{array}$ & $\begin{array}{c}1987 \\
\%\end{array}$ \\
\hline \multirow[t]{4}{*}{ The Netherlands } & $15-24$ & 21.6 & 22.0 & 21.5 & 21.6 & 21.6 & -- & 20.2 & 22.4 \\
\hline & $25-49$ & 59.7 & 61.0 & 62.1 & 62.2 & 62.2 & -- & 64.6 & 63.1 \\
\hline & $50-65$ & 17.2 & 16.3 & 15.7 & 15.6 & 15.6 & -- & 14.7 & 13.6 \\
\hline & $65+-$ & 0.5 & 0.7 & 0.6 & 0.7 & 0.7 & -- & 0.6 & 1.0 \\
\hline \multirow[t]{4}{*}{ United States } & $15-24$ & 23.0 & 23.7 & 22.9 & -- & 21.1 & 20.2 & 19.8 & 19.2 \\
\hline & $25-49$ & 54.6 & 55.2 & 56.3 & -- & 58.9 & 58.8 & 60.6 & 61.5 \\
\hline & $50-65$ & 19.3 & 18.4 & 18.1 & -- & 17.6 & 17.1 & 17.0 & 16.8 \\
\hline & $65+-$ & 3.0 & 2.7 & 2.5 & -- & 2.2 & 2.5 & 2.6 & 2.6 \\
\hline \multirow[t]{4}{*}{ Japan } & $15-24$ & 12.4 & 12.3 & 12.2 & 12.4 & 12.4 & 12.3 & 12.5 & 12.6 \\
\hline & $25-49$ & 61.6 & 61.3 & 60.9 & 60.1 & 59.8 & 59.3 & 58.6 & 58.1 \\
\hline & $50-65$ & 21.0 & 21.4 & 22.0 & 22.5 & 22.9 & 23.4 & 23.8 & 24.2 \\
\hline & $65+-$ & 4.9 & 5.0 & 5.0 & 5.0 & 5.0 & 5.0 & 5.0 & 5.1 \\
\hline \multirow[t]{4}{*}{ France } & $15-24$ & 17.2 & 16.8 & 16.7 & 16.3 & 16.0 & 15.8 & 15.3 & 13.6 \\
\hline & $25-49$ & 60.4 & 61.0 & 61.7 & 62.7 & 63.4 & 64.1 & 65.0 & 66.6 \\
\hline & $50-65$ & 21.0 & 21.0 & 20.7 & 20.1 & 19.6 & 19.2 & 18.9 & 18.9 \\
\hline & $65+-$ & 1.4 & 1.2 & 0.9 & 0.9 & 0.9 & 0.9 & 0.9 & 0.9 \\
\hline \multirow[t]{4}{*}{ (West) Germany } & $15-24$ & 20.6 & 20.8 & 20.7 & 20.8 & 21.1 & 21.2 & 20.9 & -- \\
\hline & $25-49$ & 58.1 & 57.9 & 58.0 & 58.4 & 58.1 & 58.2 & 58.2 & -- \\
\hline & $50-65$ & 19.6 & 19.8 & 20.0 & 19.6 & 19.6 & 19.5 & 19.9 & -- \\
\hline & $65+-$ & 1.6 & 1.5 & 1.3 & 1.3 & 1.2 & 1.1 & 1.0 & -- \\
\hline \multirow[t]{4}{*}{ United Kingdom } & $15-24$ & -- & 21.0 & -- & -- & -- & -- & 22.9 & -- \\
\hline & $25-49$ & -- & 53.3 & -- & -- & -- & -- & 55.3 & -- \\
\hline & $50-65$ & -- & 23.6 & -- & -- & -- & -- & 13.0 & -- \\
\hline & $65+-$ & -- & 2.0 & -- & -- & - & -- & 1.5 & -- \\
\hline \multirow[t]{4}{*}{ Sweden } & $15-24$ & 14.5 & -- & 15.7 & 15.5 & 15.5 & 15.7 & 16.2 & 16.0 \\
\hline & $25-49$ & 58.5 & -- & 58.5 & 59.1 & 59.7 & 60.1 & 60.4 & 61.3 \\
\hline & $50-65$ & 25.3 & -- & 24.2 & 23.9 & 23.5 & 22.9 & 23.4 & 22.7 \\
\hline & $65+-$ & 1.7 & -- & 1.6 & 1.5 & 1.3 & 1.3 & -- & -- \\
\hline \multirow[t]{4}{*}{ Austria } & $15-24$ & 19.7 & 25.4 & 23.3 & 23.5 & 24.6 & 24.1 & 23.9 & 23.7 \\
\hline & $25-49$ & 59.8 & 56.5 & 58.2 & 58.9 & 58.5 & 59.8 & 60.7 & 61.4 \\
\hline & $50-65$ & 19.8 & 17.3 & 17.7 & 17.0 & 16.4 & 15.6 & 14.9 & 14.4 \\
\hline & $65+-$ & 0.7 & 0.8 & 0.8 & 0.6 & 0.5 & 0.5 & 0.5 & 0.4 \\
\hline
\end{tabular}


Table 6 represents the shares of the same four age groups in the economically active population. From this table, the United States, Austria, (West) Germany, the Netherlands and the United Kingdom have a relatively young active population, whereas in Japan the share of the over-65 in the active population is relatively high. A striking feature is the relatively high proportion of active people between the ages of 50 and 65 in Japan and Sweden. That group's share even increased in Japan in the course of the 1980s. The lowest proportion of people between the ages of 50 and 65 in the active population is found in the Netherlands and Austria where moreover it declined considerably in the 1980s. The same pattern, though somewhat subdued, applies to most other countries.

With reference to the indicators discussed here, forecasts of the future share of senior citizens in the (potential) labour force might also be considered relevant to relevant elements of the indicators of age structure. Such forecasts have been drawn up for the age structures of the total population and the potential labour force (between the ages of 15 and 65 ) in the Netherlands.

Table 7A. Percentage shares of age groups in total population (the Netherlands)

\begin{tabular}{lccccccccccccccccc}
\hline age & $\begin{array}{c}1988 \\
\%\end{array}$ & $\begin{array}{c}1989 \\
\%\end{array}$ & $\begin{array}{c}1990 \\
\%\end{array}$ & $\begin{array}{c}1991 \\
\%\end{array}$ & $\begin{array}{c}1992 \\
\%\end{array}$ & $\begin{array}{c}1993 \\
\%\end{array}$ & $\begin{array}{c}1994 \\
\%\end{array}$ & $\begin{array}{c}1995 \\
\%\end{array}$ & $\begin{array}{c}2000 \\
\%\end{array}$ & $\begin{array}{c}2005 \\
\%\end{array}$ & $\begin{array}{c}2010 \\
\%\end{array}$ & $\begin{array}{c}2020 \\
\%\end{array}$ & $\begin{array}{c}2030 \\
\%\end{array}$ & $\begin{array}{c}2040 \\
\%\end{array}$ & $\begin{array}{c}2050 \\
\%\end{array}$ \\
\hline $0-14$ & 18.5 & 18.2 & 18.1 & 18.2 & 18.2 & 18.2 & 18.2 & 18.3 & 18.5 & 18.1 & 17.1 & 15.2 & 15.7 & 15.5 & 15.1 \\
$15-24$ & 16.8 & 16.4 & 15.9 & 15.4 & 14.9 & 14.4 & 13.9 & 13.3 & 11.7 & 11.8 & 12.2 & 12.2 & 10.6 & 11.2 & 11.6 \\
$25-49$ & 37.6 & 38.2 & 38.6 & 38.8 & 39.2 & 39.5 & 39.7 & 39.9 & 38.7 & 36.9 & 35.0 & 31.6 & 31.5 & 31.5 & 31.0 \\
$50-65$ & 14.6 & 14.6 & 14.6 & 14.7 & 14.7 & 14.8 & 15.0 & 15.2 & 17.3 & 19.0 & 20.5 & 22.0 & 19.9 & 17.7 & 19.8 \\
$65+-$ & 12.5 & 12.7 & 12.8 & 13.0 & 13.1 & 13.2 & 13.3 & 13.4 & 13.8 & 14.3 & 15.2 & 18.9 & 22.3 & 24.1 & 22.5 \\
\hline
\end{tabular}

Source: CBS 1989/ROA

Table 7B. Percentage shares $f$ age groups in potential labour force (the Netherlands)

\begin{tabular}{lccccccccccccccc}
\hline age & $\begin{array}{c}1988 \\
\%\end{array}$ & $\begin{array}{c}1989 \\
\%\end{array}$ & $\begin{array}{c}1990 \\
\%\end{array}$ & $\begin{array}{c}1991 \\
\%\end{array}$ & $\begin{array}{c}1992 \\
\%\end{array}$ & $\begin{array}{c}1993 \\
\%\end{array}$ & $\begin{array}{c}1994 \\
\%\end{array}$ & $\begin{array}{c}1995 \\
\%\end{array}$ & $\begin{array}{c}2000 \\
\%\end{array}$ & $\begin{array}{c}2005 \\
\%\end{array}$ & $\begin{array}{c}2010 \\
\%\end{array}$ & $\begin{array}{c}2020 \\
\%\end{array}$ & $\begin{array}{c}2030 \\
\%\end{array}$ & $\begin{array}{c}2040 \\
\%\end{array}$ & $\begin{array}{c}2050 \\
\%\end{array}$ \\
\hline $15-24$ & 24.4 & 23.7 & 23.0 & 22.3 & 21.6 & 20.9 & 20.3 & 19.5 & 17.3 & 17.4 & 18.0 & 18.6 & 17.1 & 18.5 & 18.6 \\
$25-49$ & 54.5 & 55.2 & 55.8 & 56.3 & 56.9 & 57.5 & 57.9 & 58.3 & 57.2 & 54.6 & 51.7 & 48.0 & 50.9 & 52.1 & 49.7 \\
$50-65$ & 21.2 & 21.1 & 21.2 & 21.3 & 21.4 & 21.6 & 21.9 & 22.2 & 25.5 & 28.0 & 30.3 & 33.5 & 32.0 & 29.4 & 31.7 \\
\hline
\end{tabular}

Source: CBS 1989/ROA

Tables 7A and 7B neatly show the expected declining proportion of the younger age brackets and the expanding share of the older ones. The proportion of young people (between 15 and 24 years old) in the potential labour force is expected to drop from 23.0 per cent in 1990 to only 17.4 per cent in 2005, after which it is expected to increase again slightly. By contrast, we perceive a clear increase in the share of the older age brackets (15-65) in the potential labour 
force: from 21.2 per cent in 1990 to 28.0 per cent in 2005 . Presumably, the process of aging will continue to around 2030.

\subsection{Educational efforts}

\subsubsection{Proportion of the potential labour force in post-elementary education}

The indicator introduced in this section represents the percentage of the potential labour force between the ages of 15 and 50 taking part in (non-initial) education. Schooling is an important mean to respond to technological progress. The Labour Force Survey conducted yearly by the European Community produces data on the respondents' participation in schooling during the four weeks preceding the survey. These data are available for the years between 1983 and 1988. Persons between the ages of 15 and 50 were asked to state what schooling they were participating in and for what purpose. From these data we can derive what proportion of the potential labour force between the ages of 15 and 50 participates in schooling. This indicator can be calculated in a narrow and in a wide sense. By schooling in the wide sense is understood 'on-the-job training, apprenticeship, dual system' and 'other training'. So, the indicator encompasses all types of schooling that are combined with a job (see table 8). The indicator in the narrow sense (see table 9), on the contrary, is limited to 'on-the-job training', leaving out the more elementary occupational types of training (apprenticeship etc.). To calculate the indicators, the number of people who participated in schooling in the four weeks before the survey have been related to the total population in the age brackets between 15 and 49 . These indicators can be counted as measures of the scientific and technological breeding ground for, in particular, the diffusion of technological advance.

Table 8. Participation in schooling of the potential labour force between the ages of 15 and 49 (in the wide sence)

\begin{tabular}{lcccccc}
\hline & $\begin{array}{c}1983 \\
\%\end{array}$ & $\begin{array}{c}1984 \\
\%\end{array}$ & $\begin{array}{c}1985 \\
\%\end{array}$ & $\begin{array}{c}1986 \\
\%\end{array}$ & $\begin{array}{c}1987 \\
\%\end{array}$ & $\begin{array}{c}1988 \\
\%\end{array}$ \\
\hline The Netherlands & 5 & -- & 5 & -- & 6 & 7 \\
(West) Germany & -- & 5 & 7 & 8 & 8 & 9 \\
United Kingdom & 7 & 7 & 7 & 7 & 8 & 9 \\
Italy & 1 & 1 & 1 & 1 & 2 & 2 \\
Belgium & 2 & 2 & 2 & 2 & 3 & 1 \\
Luxemburg & 3 & 3 & 3 & 3 & 3 & 3 \\
Ireland & 3 & 3 & 3 & 3 & 3 & -- \\
Denmark & -- & 13 & 15 & 15 & 16 & 1 \\
Greece & 1 & 1 & 1 & 1 & & 1 \\
\hline
\end{tabular}

Source: Eurostat/ROA 
Table 8 shows that participation in schooling in the wide sense is highest in Denmark, followed by West Germany and the United Kingdom, and extremely low in Greece and Italy. The Netherlands come fourth in the ranking. In most countries, the level of participation was more or less constant in the 1983-1988 period; in West Germany, the Netherlands and the United Kingdom a rising tendency can be perceived.

Table 9 represents participation in schooling in the narrow sense, only 'on-the-job training' being considered. The pattern of this indicator largely coincides with that of the wide indicator, although the participation in the narrow sense amounts to only one or two per cent, apart from Denmark which registers a percentage of 4 . A striking feature is the relatively low participation in schooling in West Germany la country known specifically for its well-developed initial dual education). The indicators presented here do permit comparison with other countries, but for the time only with the member states of the European Community.

Table 9. Participation in schooling of the potential labour force between the ages of 15 and 49 (in the narrow sense)

\begin{tabular}{|c|c|c|c|c|c|c|}
\hline & $\begin{array}{c}1983 \\
\% \\
\end{array}$ & $\begin{array}{c}1984 \\
\% \\
\end{array}$ & $\begin{array}{c}1985 \\
\% \\
\end{array}$ & $\begin{array}{c}1986 \\
\%\end{array}$ & $\begin{array}{c}1987 \\
\% \\
\end{array}$ & $\begin{array}{c}1988 \\
\% \\
\end{array}$ \\
\hline The Netherlands & 2 & -- & 2 & -- & 2 & 2 \\
\hline West Germany & -- & 0 & 0 & 0 & 1 & 1 \\
\hline United Kingdom & 1 & 2 & 2 & 2 & 2 & 2 \\
\hline Italy & 0 & 0 & 0 & 0 & 0 & 0 \\
\hline Belgium & 1 & 1 & 1 & 1 & 1 & 0 \\
\hline Luxemburg & 1 & 0 & 0 & 0 & 1 & 1 \\
\hline Ireland & 2 & 2 & 2 & 2 & 2 & 0 \\
\hline Denmark & 2 & 2 & 3 & 4 & 3 & 4 \\
\hline Greece & 0 & 0 & 0 & 0 & 0 & 0 \\
\hline
\end{tabular}

Source: Eurostat/ROA 


\section{INVENTARISATION AND DESCRIPTION OF COMPLEMENTARY DATA}

\subsection{Formulation of questions; method}

This chapter focuses on the efforts made to tap new sources of information and develop new indicators. To that end, some 60 national statistical offices, research, planning and forecasting institutes, and individual researchers from the United States, Japan, Sweden, (West) Germany, France and the United Kingdom have been approached by telephone or letter. Over and beyond the ROA's established international contacts we have taken addresses of contact persons and/or agencies from the lists of attendants at some international conferences for labour-market research and from documentation of Eurostat, UNESCO, OECD, CEDEFOP and ILO. We have also applied to the Embassies of the selected countries by telephone, scanned references in the literature and in letters received in answer to a first mailing. To the addresses thus collected we sent requests for information, attaching a copy of the English version of the 1989 research report (De Grip and Nusselder, 1989). The questions we put to the addressess were either general or tailored to one or a few indicators, as seemed most appropriate. Failing a written reaction within six weeks, we placed a telephone call to find out whether the letter had come to the right person; in some cases a response was thus obtained after all. So far, 47 responses have come in.

The sections 3.3-3.7 present the figures found in the various publications collected. We have broken them down into data indicative of demographic developments (section 3.3), labourmarket data (section 3.4), educational data (section 3.5), data on training (section 3.6), and other data (section 3.7). In every case we suggest new indicators that might either be constructed forthwith from the data now available, or seem promising but for which the present data are not yet sufficient. We also mention which indicators permit yearly updating.

Section 3.2 reports on the attempts - mostly vain - made to produce instantly usable complements to the key indicators described in chapter 2. We have indeed gathered an abundance of data which interface with the existing key indicators, but many of them are available for only one or a few countries. Occasionally we found information that might help to strengthen the existing key indicators. Whenever relevant figures were unearthed for non-selected Western industrialised countries, they were added to the tables concerned.

Most of the new data can be considered indicative of the scientific and technological breeding ground for R\&D; some others are indicative of the societal breeding ground for technological advance, or the economic effects of R\&D. We have also included some data that may function 
as variables representing economic, demographic and/or backgrounds.

\subsection{Completion of existing key indicators}

Some of the six key indicators presented in chapter 2 lacked figures for certain countries, for instance non-EC members. Sometimes the figures were only known for the Netherlands. In the second part of the research project efforts have been made to fill the blanks from complementary statistics. The key indicators can be arranged as follows:

- Initial education:

1. Participation in dual education

2. Share of vocational education in total regular education

- Labour force and schoolleavers:

3. Proportion of technicians among schoolleavers and labour force

- Need for schooling:

4. Indicators of tension (technicians)

5. Age composition of (active) population

- Efforts towards schooling:

6. Proportion of labour force participating in schooling

Below we will specify for each indicator which data for which countries needed completion, and to what extent the additional information has been found.

\section{Participation in dual education}

Since this indicator is based on Eurostat data, figures from non-EC countries were lacking. Complementary data have been found for Sweden; in that country, 'vocational training' consists for a minute part in the share of 'apprenticeship training' in (less than 1 per cent). 'Apprenticeships' occur only with a few specialist companies, or occasionally to round off a 'gymnasial vocational course'. To add Sweden to to table 1 we should need to establish absolute figures. In the United States there is no (formal) dual schooling, but company-specific 'on-the-job training' is an important factor.

\section{Participation in vocational education}

This indicator is based on UNESCO data. However, no figures are available for the United States, nor have they been found in the data material sent to us. 


\section{Share of technicians}

This indicator is based on the Skill-model estimates of the Dutch Ministry of Education and Sciences. For the other countries except Japan, forecasts have been traced for employment by level of education, for technicians, technically schooled persons, or employees in the sector 'Technique'. These figures are presented in table 26. Because their value is variable and their significance depends on the models used and on the underlying assumptions, we cannot yet accept them as suitable complements.

\section{Tension indicators for technicians}

Like the previous one, this indicator is based on Dutch figures. The figures received from other countries are less detailed; they are unemployment data mostly referring to leavers of technical schools.

Age structure of the (active) population

The figures of the age structure of the active population had been borrowed from ILO-statistics. They are available for all seven countries. They have been completed with forecasts for the Netherlands. Forecasts for Sweden, the United States, France and (West) Germany are represented in table 10. A further search for forecasts matching the ILO-data is necessary. Section 3.3 reports on forecasts of the median age of the labour force, broken down, moreover, by sector and occupational group.

\section{Schooling of the labour force}

This indicator is based on Eurostat data and therefore contains no figures for non-EC countries. From the United States, Japan and Sweden no figures have been received that could be considered a reliable completion.

The overall conclusion must be that the data available on the national levels produce hardly any suitable additions to the key indicators mentioned. Only a co-ordinated international effort could produce indicators at all comparable. To that end, non-published data need to be made available, and several problems of adjustment (different classifications and definitions, etc.) solved. 


\subsection{Demographic developments}

Section 2.3.2 contains a number of historical time series of the age structure of the total population and the active labour force. They give a clear picture of the declining proportion of young persons and the general aging of the population up to this moment. This section presents some forecasts to complete that picture.

\section{Forecasts of the median age brackets}

Van der Wijst (1987) drew up some forecasts of changes in the median age of the labour force in several countries, in the framework of the project 'Economic and Social Implications of Changing Age Distribution' undertaken for the Economic Commission of Europe (ECE) of the United Nations (see table 10).

Table 10. Forecasts of the median age of the labour force in 1980, 2010 en 2025 (in years)

\begin{tabular}{|c|c|c|c|c|c|}
\hline & $\begin{array}{c}\text { around } \\
1980 \\
\end{array}$ & 2010 & 2025 & $\begin{array}{c}\text { change } \\
1980-2010\end{array}$ & $\begin{array}{c}\text { change } \\
2010-2025 \\
\end{array}$ \\
\hline The Netherlands & 34.2 & 40.9 & 41.1 & +6.7 & +0.2 \\
\hline United States & 35.5 & 39.8 & 38.8 & +4.3 & -1.0 \\
\hline France & 37.7 & 39.3 & 39.3 & +1.6 & 0 \\
\hline (West) Germany & 37.9 & 41.2 & 40.0 & +3.3 & -1.2 \\
\hline Sweden & 39.3 & 41.8 & 42.7 & +2.5 & +0.9 \\
\hline
\end{tabular}

Source: ILO (1986); Calculations: Van der Wijst 1987 (1)

According to these forecasts, by 2010 the Netherlands will have the third oldest labour force after West Germany and Sweden. That is the more remarkable as around 1980 the Netherlands still had the second youngest labour force. How such a change affects the labour market depends largely on the participation degree of senior citizens. Another conclusion is that the changes between 2010 and 2025 will be far less drastic than those between 1980 and 2010 . By 2025 the median age in many countries is expected to drop below that of 2010 as the 'baby-boom generations' ebb away (Van der Wijst, 1987-1).

\section{Development of the potential (active) population}

By commission of the (West-)German Institut für Arbeitsmarkt- und Berufsforschung (IAB), the Swiss research bureau Prognos AG has drawn up forecasts of the development of the labour force in the 12 EC member states (see Prognos, 1990). Figure 1 pictures the results. The figures are useful as a background indicator of the economies' (technological) development 
potential.

Figure 1: Population and labour force of the EC: percentage change from 1987 to 2000

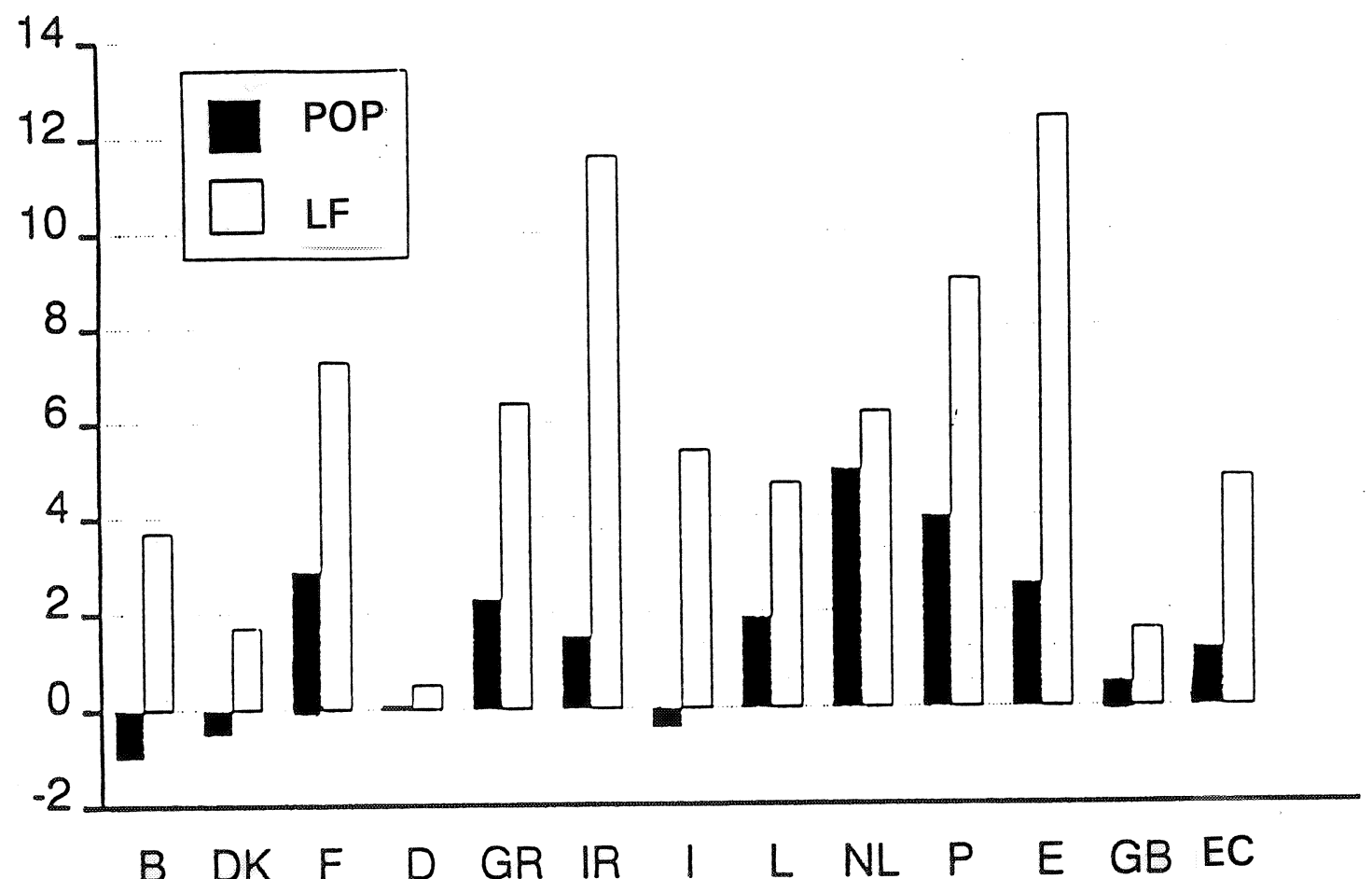

Source: Prognos AG

At the 6-percent growth rate envisaged by these forecasts, the Netherlands will remain the fastest growing EC member state, in demographic terms, until 2000. The growth rate of the population will even be surpassed by one percentage point by that of the labour force. Very high growth rates (between 9 and 12.5 per cent) of the labour force are expected for Spain, Ireland, and Portugal, which modifies considerably the conclusion of section 2.3.2 about possible consequences of demographic aging.

\section{Median age by sector}

Sectors will be affected in varying degrees by the aging of the population. Especially the changes in median age indicate the stagnation of the inflow of young people into each particular sector. 
Table 11. Forecasts of the median age by sector* (in years)

\begin{tabular}{lccccccccccc}
\hline & \multicolumn{2}{c}{ The Netherlands } & \multicolumn{2}{c}{ United States } & \multicolumn{2}{c}{ France } & \multicolumn{2}{c}{ (West) Germany } & \multicolumn{2}{c}{ Sweden } \\
& 2010 & $1981-2010$ & 2010 & $1981-2010$ & 2010 & $1981-2010$ & 2010 & $1981-2010$ & 2010 & $1981-2010$ \\
\hline Agriculture & 47.2 & +6.0 & 44.4 & +5.3 & 48.8 & +0.7 & 48.6 & +1.5 & 49.0 & +0.9 \\
Mineral Extraction & 36.1 & +4.4 & 39.0 & +5.0 & 43.3 & +2.0 & 44.3 & +3.4 & 42.6 & +2.6 \\
Manufacturing & 42.4 & +6.7 & 41.8 & +5.0 & 39.7 & +2.6 & 41.8 & +3.1 & 41.9 & +2.7 \\
Electricity, gas & 45.0 & +5.4 & 42.5 & +4.8 & 40.2 & +2.4 & 45.0 & +2.7 & 43.7 & +2.4 \\
and water & & & & & & & & & & \\
Construction & 40.2 & +6.1 & 40.3 & +5.3 & 39.4 & +2.4 & 41.3 & +3.0 & 40.8 & +2.3 \\
Commerce & 40.5 & +6.9 & 38.1 & +5.9 & 39.6 & +2.6 & 40.5 & +3.2 & 42.1 & +2.5 \\
Transport & 41.7 & +6.7 & 42.1 & +4.2 & 40.0 & +2.4 & 42.2 & +2.8 & 41.4 & +2.6 \\
Business and & 39.5 & +6.9 & 40.0 & +5.2 & 38.0 & +2.8 & 38.9 & +3.0 & 41.6 & +2.1 \\
Public Services & & & & & & & & & & \\
Other Services & 39.9 & +6.8 & 41.5 & +4.8 & 39.3 & +2.4 & 39.5 & +3.6 & 40.9 & +2.5 \\
\hline
\end{tabular}

* Under the assumption that the distribution by sector remains equal to 1980 Source: ILO (1986); Calculations: Van der Wijst 1987 (1)

Table 11 shows that in the Netherlands, the sectors Mineral Extraction, Construction, Commerce, and Business and Public Services will employ relatively young workers by 2010. Strikingly, of the five countries examined, the Netherlands will display the strongest growth of the median age in all sectors.

Table 12. Forecasts of the median age by occupational class (in years)

\begin{tabular}{|c|c|c|c|c|c|c|c|c|c|}
\hline & \multirow[b]{2}{*}{ code } & \multicolumn{2}{|c|}{ The Netherlands } & \multicolumn{2}{|c|}{ United States } & \multicolumn{2}{|c|}{ (West) Germany } & \multicolumn{2}{|c|}{ Sweden } \\
\hline & & 2010 & $1981-2010$ & 2010 & $1981-2010$ & 2010 & $1981-2010$ & 2010 & $1981-2010$ \\
\hline $\begin{array}{l}\text { Academic and other } \\
\text { proffesional specialists }\end{array}$ & $(0-1)$ & 39.6 & +6.0 & 39.9 & +4.4 & 40.4 & +2.6 & 40.2 & +2.2 \\
\hline $\begin{array}{l}\text { Managing and higher } \\
\text { executive functions }\end{array}$ & (2) & 47.1 & +3.6 & 43.8 & +3.7 & 45.8 & +2.0 & 46.5 & +1.3 \\
\hline Administrative functions & (3) & 39.4 & +7.5 & 39.6 & +5.5 & 40.2 & +3.2 & 41.5 & +2.5 \\
\hline Commercial functions & (4) & 42.4 & +6.0 & 41.3 & +5.7 & 41.2 & +2.9 & 43.6 & +2.1 \\
\hline Services & (5) & 41.3 & +5.3 & 40.3 & +6.3 & 39.4 & +4.4 & 43.4 & +2.7 \\
\hline Agrarian occupations & (6) & 47.4 & +5.7 & 44.2 & +5.4 & 48.5 & +1.5 & 48.9 & +0.9 \\
\hline $\begin{array}{l}\text { Technical, manufacturing } \\
\text { and transport occupations }\end{array}$ & $(7,8,9)$ & 40.8 & +6.6 & 40.6 & +5.6 & 41.2 & +3.4 & 40.6 & +0.3 \\
\hline
\end{tabular}

* Under the assumption that the distribution by occupational class remains equal to 1980

Source: ILO (1986); Calculations: Van der Wijst 1989 (1)

Table 12 shows that especially the occupational sectors 'Academic- and other professional specialists' and 'Administrative functions' have the lowest median age. However, these occupational classes will, at least in the Netherlands, be confronted with a high degree of ageing of the workforce.

\section{Decline of the proportion of young people}

The Department of Education and Science of the United Kingdom has drawn up forecasts of the evolution of the number of young people in the 16-18 age bracket in 13 countries (Table 13 
and figure 2).

Table 13. Standardised unemployment, in percentages of the labour force

\begin{tabular}{|c|c|c|c|c|c|c|c|}
\hline year & France & (West) Germany & Japan & The Netherlands & Sweden & United Kingdom & United States \\
\hline 1968 & 103 & 103 & 109 & 100 & 104 & 102 & 97 \\
\hline 1970 & 100 & 100 & 100 & 100 & 100 & 100 & 100 \\
\hline 1972 & 99 & 100 & 93 & 100 & 98 & 99 & 104 \\
\hline 1974 & 100 & 103 & 89 & 102 & 98 & 104 & 107 \\
\hline 1976 & 100 & 109 & 89 & 104 & 97 & 109 & 107 \\
\hline 1978 & 100 & 120 & 89 & 110 & 95 & 116 & 106 \\
\hline 1980 & 100 & 125 & 91 & 112 & 99 & 121 & 102 \\
\hline 1981 & 101 & 127 & 95 & 112 & 105 & 123 & 99 \\
\hline 1982 & 102 & 128 & 92 & 112 & 109 & 123 & 94 \\
\hline 1983 & 101 & 127 & 95 & 110 & 112 & 122 & 90 \\
\hline 1984 & 99 & 125 & 96 & 108 & 111 & 119 & 89 \\
\hline 1985 & 100 & 122 & 104 & 107 & 108 & 120 & 91 \\
\hline 1986 & 100 & 116 & 105 & 109 & 104 & 118 & 92 \\
\hline 1987 & 100 & 108 & 108 & 109 & 100 & 115 & 94 \\
\hline 1988 & 102 & 100 & 110 & 107 & 101 & 114 & 92 \\
\hline 1990 & 103 & 83 & 114 & 96 & 102 & 106 & 83 \\
\hline 1992 & 94 & 71 & 108 & 84 & 99 & 94 & 80 \\
\hline 1994 & 86 & 69 & 99 & 79 & 91 & 87 & 81 \\
\hline 1996 & 87 & 68 & 92 & 78 & 87 & 87 & 85 \\
\hline 1998 & 92 & 71 & & 79 & 88 & 94 & \\
\hline 2000 & 90 & 72 & & 76 & 86 & 94 & \\
\hline
\end{tabular}

Source: Department of Education and Sciences (DES), 1990

The European countries, the United States, and Japan show remarkable differences on that score. In the US the decline set in as far back as 1975, while in Japan it is expected from 1990 onwards. For all West-European countries the turning point lies between 1980 and 1990 . Fance recorded hardly any change in the volume of the 16-18 age bracket from 1968 to 1988 . In (West) Germany, on the contrary, a 11-percent rise occurred around 1977, while between 1985 and 1990 a drop of nearly 40 per cent is expected. In the Netherlands an 11-percent drop has been recorded between 1988 and 1990. The developments in Sweden and the United Kingdom have been more gradual.

Mark that the forecasts by Van der Wijst, Prognos AG and the British Department of Education and Science are of an occasional nature, and that there will be no annual updating from the same sources. Perhaps the results of some United Nations studies, regrettably not available in time for this report, will make updating possible. That would be worth investigating. 
Figure 2: Evolution of the proportion of 16 to 18 -year-olds, index figures $(1970=100)$

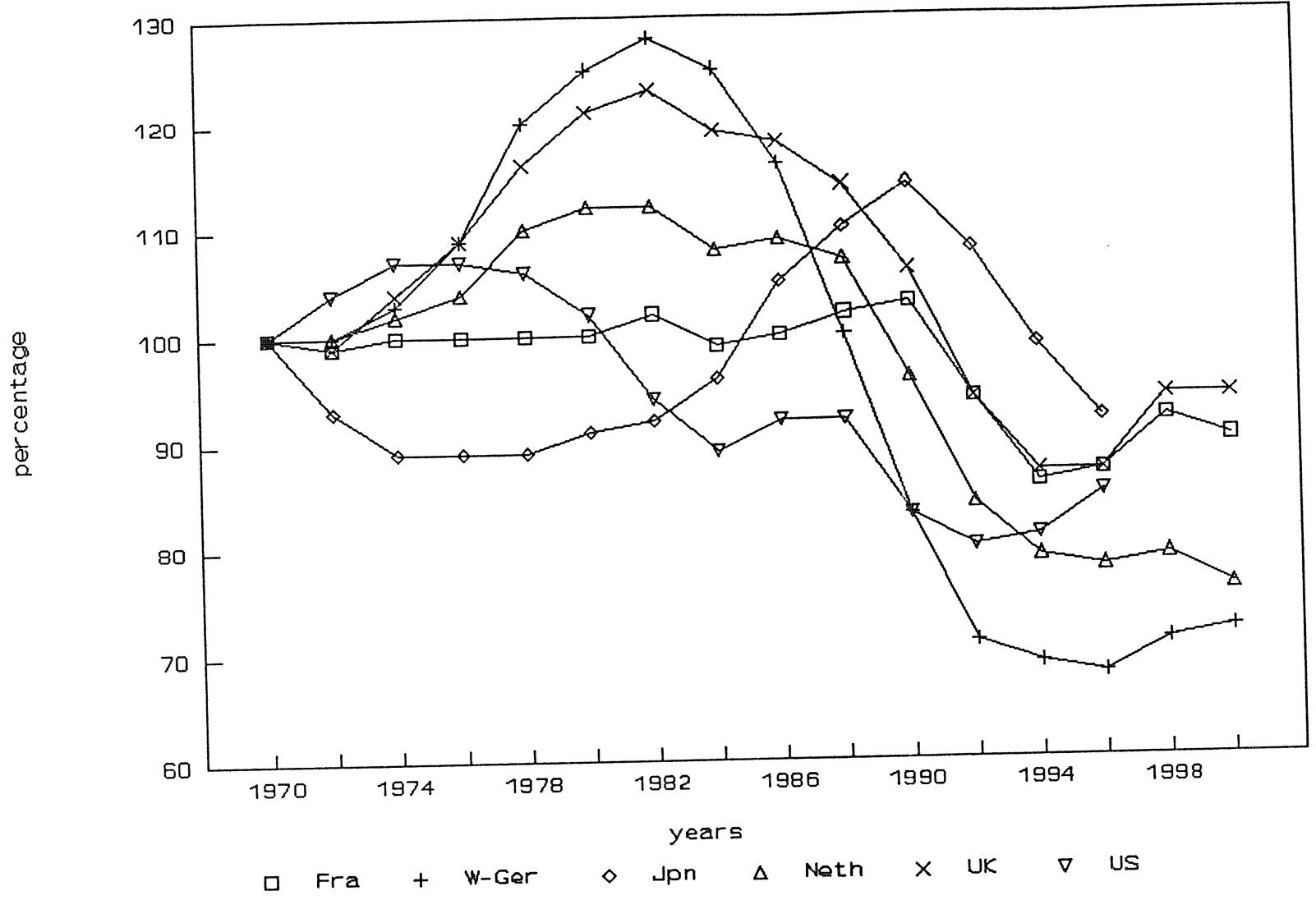

\subsection{Labour-market data}

\subsubsection{Bottlenecks on the labour market}

Unemployment data are indicative of bottlenecks on the labour market and hence of impediments to the diffusion of technological advance due to a short supply of labour.

\section{Unemployment rates}

Table 14 gives a survey of standardised unemployment, in percentages of the labour force.

From the table, most countries in Western Europe appear to sustain relatively high unemployment in comparison with Sweden, Japan and the United States. Only in Sweden and Japan can the labour market on the whole be said to be tight. 
Table 14. Standardised unemployment, in percentages of the labour force

\begin{tabular}{lccccccc}
\hline & $\begin{array}{c}1979 \\
\%\end{array}$ & $\begin{array}{c}1983 \\
\%\end{array}$ & $\begin{array}{c}1984 \\
\%\end{array}$ & $\begin{array}{c}1985 \\
\%\end{array}$ & $\begin{array}{c}1986 \\
\%\end{array}$ & $\begin{array}{c}1987 \\
\%\end{array}$ & $\begin{array}{c}1988 \\
\%\end{array}$ \\
\hline The Netherlands & 5.4 & 12.0 & 11.8 & 10.6 & 9.9 & 9.6 & 9.5 \\
United States & 5.8 & 9.5 & 7.4 & 7.1 & 6.9 & 6.1 & 5.4 \\
Japan & 2.1 & 2.6 & 2.7 & 2.6 & 2.8 & 2.8 & 2.5 \\
France & 5.9 & 8.3 & 9.7 & 10.2 & 10.4 & 10.5 & 10.3 \\
(West) Germany & 3.2 & 8.0 & 7.1 & 7.2 & 6.4 & 6.2 & 6.2 \\
United Kingdom & 5.0 & 12.4 & 11.7 & 11.2 & 11.2 & 10.2 & 8.3 \\
Sweden & 2.1 & 3.5 & 3.1 & 2.8 & 2.7 & 1.9 & 1.6 \\
\hline
\end{tabular}

Source: OECD, Quarterly Labour Force Statistics, no. 4-1988

Shortages of skilled labour

Table 15. Proportion of companies short of expert labour

\begin{tabular}{|c|c|c|c|}
\hline & $\begin{array}{c}\text { Sweden* } \\
\%\end{array}$ & $\begin{array}{c}\text { United Kingdom* } \\
\%\end{array}$ & $\begin{array}{c}\text { France } \\
\%\end{array}$ \\
\hline 1979 & 37.1 & 21.1 & 5.0 \\
\hline 1980 & 45.4 & 8.4 & 5.0 \\
\hline 1981 & 20.8 & 2.5 & 2.5 \\
\hline 1982 & 13.1 & 3.0 & 4.0 \\
\hline 1983 & 18.3 & 4.4 & 4.0 \\
\hline 1984 & 30.0 & 8.2 & 3.0 \\
\hline 1985 & 31.3 & 13.2 & 3.8 \\
\hline 1986 & 33.8 & 11.7 & 2.5 \\
\hline 1987 & 44.8 & 14.2 & 1.8 \\
\hline 1988 & 59.0 & 22.0 & 4.3 \\
\hline
\end{tabular}

* shortage of skilled workers

* general shortage of labour force

Source: OECD, 1989

Table 15 lists the industries that suffer from a shortage of skilled workers. The display is taken from the Employment Outlook 1989. For the Netherlands no directly comparable information is available. Perhaps more or less comparable figures could be constructed from the CBS vacancy survey.

In Sweden, a remarkably high, and still rising, proportion of companies admit to labour shortages. In Great Britain, too, the tendency is rising, despite the relatively high unemployment figures.

\section{Youth unemployment}

Youth unemployment is obviously another indicator of the incidence of bottlenecks on the 
labour market. On the other hand, young unemployed people, provided they have the right previous education, are open to special types of vocational training and therefore constitute a significant schooling potential. Table 16 shows the percentages of unemployed young people (between the ages of 15 and 24).

Table 16. Unemployment rate among 15-24-year-olds

\begin{tabular}{lcc}
\hline & $\begin{array}{c}1983 \\
\%\end{array}$ & $\begin{array}{c}1989 \\
\%\end{array}$ \\
\hline The Netherlands & 22.7 & 16.0 \\
France & 21.5 & 21.2 \\
(West) Germany & 11.6 & 5.2 \\
United Kingdom & 20.5 & 8.8 \\
Italy & 30.9 & 32.3 \\
Belgium & 27.6 & 17.4 \\
Luxemburg & 8.1 & 3.8 \\
Ireland & 22.3 & 22.2 \\
Denmark & 17.9 & 10.2 \\
Portugal & 18.6 & 11.3 \\
Spain & 42.6 & 35.7 \\
\hline
\end{tabular}

Source: Eurostat

From the table, Italy is the only country where youth unemployment has continued to rise in the last decade. In the Netherlands a substantial decline has occurred, but the rate of unemployment among youngsters is still high.

\section{Unemployment by level of education}

In the Employment Outlook 1989, the OECD drew up a survey of the rate of unemployment by level of education (see table 17). We present here the data for the Netherlands, West Germany, the United States, the United Kingdom, and Sweden. By level A are understood the lowest skilled (secondary vocational, general secondary, or elementary). Given the relatively bad 'corruption' of Dutch unemployment figures, the offhand conclusion that on the whole the Dutch labour market for young people is easy, would lack caution. The corrected unemployment rates for schoolleavers given in table 4 are significant in that context. Level B refers to the higher level of secondary education, pre-university education, etc.; level $D$ refers to higher vocational education, and level E to university graduates. Probably, the figures presented here give a somewhat distorted image on account of different classifications. 
$-25-$

Table 17. Unemployment by level of education, age and sex, 1988, in percentages

\begin{tabular}{|c|c|c|c|c|c|c|c|c|c|c|c|c|}
\hline \multirow[t]{2}{*}{ Level of education } & \multicolumn{6}{|c|}{ Men } & \multicolumn{6}{|c|}{ Women } \\
\hline & $\begin{array}{c}\text { TOTAL } \\
\% \\
\end{array}$ & $\begin{array}{c}\text { age } \\
20-24 \\
\% \\
\end{array}$ & $\begin{array}{c}\text { age } \\
25-34 \\
\%\end{array}$ & $\begin{array}{c}\text { age } \\
35-44 \\
\%\end{array}$ & $\begin{array}{c}\text { age } \\
45-54 \\
\% \\
\end{array}$ & $\begin{array}{c}55 \text { jaar en } \\
\text { ouder } \\
\%\end{array}$ & $\begin{array}{c}\text { TOTAL } \\
\% \\
\end{array}$ & $\begin{array}{c}\text { age } \\
20-24 \\
\% \\
\end{array}$ & $\begin{array}{c}\text { age } \\
25-34 \\
\% \\
\end{array}$ & $\begin{array}{c}\text { age } \\
35-44 \\
\% \\
\end{array}$ & $\begin{array}{c}\text { age } \\
45-54 \\
\%\end{array}$ & $\begin{array}{c}55 \text { jaar } \\
\text { en ouder } \\
\% \\
\end{array}$ \\
\hline \multicolumn{13}{|l|}{ The Netherlands } \\
\hline Total & 7.5 & 10.4 & 7.3 & 5.6 & 6.1 & 13.1 & 13.2 & 12.6 & 13.6 & 14.3 & 11.6 & 12.8 \\
\hline Level A & 10.9 & 11.8 & 10.7 & 9.0 & 9.2 & 18.1 & 16.5 & 16.9 & 19.3 & 16.8 & 12.8 & 4.7 \\
\hline Level B & 4.8 & 8.1 & 4.3 & 3.3 & 3.7 & 9.1 & 10.3 & 8.7 & 9.9 & 12.7 & 10.9 & 6.9 \\
\hline Level D & 4.3 & 12.0 & 5.2 & 2.6 & 2.9 & 9.3 & 10.7 & 15.0 & 9.4 & 10.6 & 9.5 & 20.0 \\
\hline Level E & 4.4 & -- & 7.6 & 3.0 & 2.3 & 4.2 & 11.4 & -- & 15.2 & 8.0 & 14.3 & -- \\
\hline \multicolumn{13}{|l|}{ United States } \\
\hline Total & 5.6 & 10.2 & 6.4 & 4.7 & 3.8 & 3.9 & 4.8 & 8.9 & 5.4 & 4.3 & 3.0 & 2.4 \\
\hline Level A & 10.7 & 19.1 & 13.9 & 10.7 & 6.7 & 6.5 & 9.6 & 22.2 & 13.9 & 9.6 & 5.5 & 4.3 \\
\hline Level B & 6.7 & 10.4 & 7.6 & 6.1 & 4.5 & 3.7 & 5.4 & 11.0 & 6.1 & 5.1 & 3.1 & 1.8 \\
\hline Level D & 4.3 & 6.6 & 4.2 & 4.0 & 3.3 & 3.2 & 3.6 & 4.7 & 4.4 & 3.4 & 2.2 & 1.1 \\
\hline Level E & 1.8 & 5.5 & 2.3 & 1.3 & 1.2 & 1.6 & 2.1 & 4.2 & 2.4 & 1.6 & 1.1 & 2.5 \\
\hline \multicolumn{13}{|l|}{ (West) Germany } \\
\hline Total & 6.9 & 10.3 & 7.8 & 5.6 & 5.6 & 7.3 & 9.4 & 9.6 & 11.1 & 8.6 & 7.8 & 9.1 \\
\hline Level A & 14.4 & 17.5 & 19.8 & 13.9 & 11.4 & 11.4 & 12.9 & 17.6 & 18.0 & 12.7 & 9.4 & 10.0 \\
\hline Level B & 5.5 & 9.2 & 9.1 & 3.4 & 2.2 & 2.1 & 8.1 & 8.0 & 12.8 & 4.5 & 3.9 & 7.9 \\
\hline Level C & 5.9 & 8.1 & 5.9 & 5.0 & 4.9 & 7.6 & 8.2 & 7.4 & 9.1 & 8.1 & 7.4 & 9.1 \\
\hline Level D & 3.0 & 8.3 & 3.6 & 3.0 & 2.0 & 4.0 & 8.8 & 8.7 & 10.5 & 8.3 & 7.4 & -- \\
\hline Level E & 3.0 & 20.0 & 5.2 & 2.6 & 1.7 & 1.2 & 6.9 & 16.7 & 11.1 & 4.6 & 3.6 & 2.3 \\
\hline \multicolumn{13}{|l|}{ United Kingdom } \\
\hline Total & 10.4 & 15.3 & 11.5 & 7.8 & 8.8 & 11.2 & 9.7 & 13.9 & 12.9 & 7.7 & 6.7 & 7.4 \\
\hline Level A & 14.8 & 19.9 & 17.9 & 11.6 & 12.1 & 11.8 & 11.3 & 16.8 & 15.9 & 8.1 & 7.5 & 7.0 \\
\hline Level B & 7.7 & 11.8 & 5.8 & 5.3 & -- & -- & 7.0 & 7.2 & 8.4 & -- & -- & -- \\
\hline Level C & 8.1 & 8.4 & 8.7 & 6.4 & 7.9 & 12.1 & 10.1 & 11.8 & 12.3 & 13.3 & -- & -- \\
\hline Level E & 3.7 & 5.4 & 2.5 & 1.5 & - & 4.6 & 4.7 & -- & 6.0 & 4.7 & -- & -- \\
\hline \multicolumn{13}{|l|}{ Sweden } \\
\hline Total & 1.8 & 4.3 & 2.1 & 1.1 & 0.8 & 2.0 & 1.8 & 4.3 & 2.1 & 1.0 & 0.8 & 2.0 \\
\hline Level A & 2.1 & 6.6 & 3.2 & 1.2 & 1.1 & 2.1 & 2.2 & 7.5 & 3.4 & 1.7 & 0.9 & 2.1 \\
\hline Level B & 1.4 & 3.1 & 2.0 & 0.7 & 0.3 & 2.1 & 1.5 & 2.4 & 1.7 & 0.8 & 0.0 & 3.8 \\
\hline Level C & 2.2 & 3.9 & 1.9 & 1.4 & 0.2 & 1.9 & 2.1 & 3.9 & 1.6 & 1.3 & 0.9 & 1.9 \\
\hline Level D & 1.4 & 3.2 & 1.3 & 0.9 & 0.9 & 1.5 & 0.8 & 1.6 & 0.7 & 0.8 & 0.5 & 1.1 \\
\hline Level E & 0.8 & 2.9 & 1.0 & 0.8 & 0.4 & 0.6 & 0.8 & 3.6 & 1.2 & 0.6 & 0.4 & 0.5 \\
\hline
\end{tabular}

Source: OECD (1989)

$A=$ Level $A$, completed less than upper secondary education

$B=$ Level $B$, completed upper secondary education

$\mathrm{C}=$ Level $\mathrm{C}$, vocational, non-academic educational training

$\mathrm{D}=$ Level $\mathrm{D}$, completed some post-secondary education, but not a university degree

$E=$ Level $E$, completed at least one university degree

Legend: -- = unknown 
Table 18. Ratio between unemployment rates of persons of level-A education and level-education

\begin{tabular}{lll}
\hline & Men & Women \\
\hline The Netherlands & 2.48 & 1.45 \\
United States & 5.94 & 4.57 \\
(West) Germany & 4.80 & 1.87 \\
United Kingdom & 4.00 & 2.40 \\
Italy & 1.87 & 1.66 \\
Belgium & 2.31 & 2.91 \\
Sweden & 2.63 & 2.75 \\
Australia & 3.65 & 1.42 \\
Austria & 6.88 & 2.04 \\
Canada & 3.59 & 2.42 \\
Finland & 7.50 & 8.00 \\
Greece & 0.93 & 0.49 \\
Norway & 5.50 & 2.00 \\
Spain & 1.17 & 0.17 \\
Switzerland & 1.00 & 0.86 \\
\hline
\end{tabular}

Source: OECD (1989)

From table 17 it is evident that in all countries unemployment is relatively highest among the lowest skilled, youngsters and women. From table 17 the OECD has evolved table 18, which relates unemployment among the lowest skilled to that among the highest skilled. A high ratio thus represents much unemployment among the lowest skilled. The ratios appear to be on the whole much higher for men than for women, with the exception of Belgium, Finland and Sweden. In Finland and the United States the ratios are high for both sexes. Only in Greece, Spain and Switzerland are the unemployment rates the same for low- and high-skilled people.

\subsubsection{Labour force by level of education}

The indicators presented in tables 19 and 20 are the percentages of the active labour force with level-A and level-E educations, respectively. The tables have been borrowed from the OECD Employment Outlook 1989 and completed with Dutch figures taken from the 1985 LabourForce Survey.

From table 19, the proportion of the active labour force with a level-A education is lowest in the United States, followed by the Netherlands and (West) Germany. A high proportion of lowskilled workers suggests a possible bottleneck for the innovation and diffusion potential of technological advance. As already pointed out above, the data have to be interpreted conservatively in view of possible classification differences. That applies in particular to the educational information deriving from the Labour-Force Survey, which the Dutch Central Bureau of 
Statistics (CBS) itself considers insufficiently reliable.

Table 19. Annual percentage changes in the proportion of active population with level-A education

\begin{tabular}{|c|c|c|c|c|c|c|}
\hline & $\begin{array}{c}\text { The Netherlands* } \\
(1985) \\
\% \\
\end{array}$ & $\begin{array}{c}\text { (West) Germany } \\
\% \\
\end{array}$ & $\begin{array}{c}\text { Japan } \\
\% \\
\end{array}$ & $\begin{array}{c}\text { Sweden } \\
\% \\
\end{array}$ & $\begin{array}{c}\text { United } \\
\text { Kingdom } \\
\%\end{array}$ & $\begin{array}{c}\text { United States } \\
(1988) \\
\% \\
\end{array}$ \\
\hline $\begin{array}{l}\text { Agriculture and } \\
\text { fishing }\end{array}$ & 22.8 & 50.6 & 65.9 & 67.5 & 74.7 & 32.9 \\
\hline Mineral Extraction & 18.2 & 29.9 & 47.1 & & 56.2 & 16.2 \\
\hline Manufacturing & 28.0 & 26.9 & 32.1 & 50.1 & 57.5 & 20.6 \\
\hline $\begin{array}{l}\text { Electricity, water and } \\
\text { gas }\end{array}$ & 18.2 & 14.3 & 12.1 & & 42.6 & \\
\hline Construction & 22.5 & 23.8 & 43.7 & 46.2 & 46.6 & 25.0 \\
\hline Trade and catering & 25.4 & 23.7 & 23.4 & 52.7 & 71.9 & 21.6 \\
\hline $\begin{array}{l}\text { Transport, storage } \\
\text { and communication }\end{array}$ & 29.1 & 19.5 & 27.9 & 51.5 & 62.5 & 11.6 \\
\hline $\begin{array}{l}\text { Banking, insurance } \\
\text { and commercial } \\
\text { services }\end{array}$ & 14.7 & 11.3 & 9.5 & 31.1 & 49.8 & 5.3 \\
\hline Other services & 14.4 & 16.3 & 17.2 & 35.5 & 46.9 & 11.9 \\
\hline Total & 20.9 & 22.5 & 29.2 & 44.1 & 56.2 & 16.4 \\
\hline
\end{tabular}

Source: OECD (1989), (figures 1987)

* CBS/ROA (figures 1985 )

Table 20. Annual percentage changes in the proportion of active population with level-E education

\begin{tabular}{|c|c|c|c|c|c|c|}
\hline & $\begin{array}{c}\text { The Netherlands* } \\
(1985) \\
\% \\
\end{array}$ & $\begin{array}{c}\text { (West) Germany } \\
\% \\
\end{array}$ & $\begin{array}{c}\text { Japan } \\
\% \\
\end{array}$ & $\begin{array}{c}\text { Sweden } \\
\% \\
\end{array}$ & $\begin{array}{c}\text { United } \\
\text { Kingdom } \\
\%\end{array}$ & $\begin{array}{c}\text { United States } \\
(1988) \\
\% \\
\end{array}$ \\
\hline $\begin{array}{l}\text { Agriculture and } \\
\text { fishing }\end{array}$ & 0.4 & 0.7 & 1.1 & 2.1 & 5.5 & 10.3 \\
\hline Mineral Extraction & 9.1 & 2.1 & 10.3 & & 5.4 & 23.5 \\
\hline Manufacturing & 1.8 & 2.7 & 11.7 & 4.9 & 10.4 & 18.1 \\
\hline $\begin{array}{l}\text { Electricity, water and } \\
\text { gas }\end{array}$ & 2.3 & 2.9 & 16.7 & & 19.2 & \\
\hline Construction & 0.8 & 1.2 & 9.0 & 2.2 & 8.5 & 9.0 \\
\hline Trade and catering & 0.9 & 2.2 & 12.7 & 4.8 & 5.6 & 12.9 \\
\hline $\begin{array}{l}\text { Transport, storage } \\
\text { and communication }\end{array}$ & 1.2 & 1.4 & 8.6 & 4.2 & 7.0 & 17.8 \\
\hline $\begin{array}{l}\text { Banking, insurance } \\
\text { and commercial } \\
\text { services }\end{array}$ & 8.5 & 8.4 & 27.1 & 17.4 & 24.6 & 29.6 \\
\hline Other services & 9.8 & 14.8 & 24.9 & 19.8 & 33.1 & 34.8 \\
\hline Total & 4.7 & 6.3 & 14.5 & 11.1 & 17.0 & 23.4 \\
\hline
\end{tabular}

Source: OECD (1989), (figures 1987)

* CBS/ROA (figures 1985)

The Netherlands and West Germany score relatively lowest on the proportion of the active labour force with a level-E education. The United Kingdom and the United States, by contrast, 
boast a relatively high proportion of university graduates, which can be considered indicative of a great innovation and diffusion potential of technological advance.

Table 21. Annual percentage changes in the proportion of active population with level-A education

\begin{tabular}{|c|c|c|c|c|c|c|}
\hline $\begin{array}{l}\text { eerste meting } \\
\text { tweede meting } \\
\end{array}$ & $\begin{array}{c}\text { The Netherlands* } \\
1979 \\
1985 \\
\end{array}$ & $\begin{array}{c}\text { (West) Germany } \\
1978 \\
1987 \\
\end{array}$ & $\begin{array}{l}\text { Japan } \\
1974 \\
1987 \\
\end{array}$ & $\begin{array}{c}\text { Sweden } \\
1971 \\
1987 \\
\end{array}$ & $\begin{array}{c}\text { United Kingdom } \\
\begin{array}{c}1981 \\
1987 \\
\end{array} \\
\end{array}$ & $\begin{array}{c}\text { United States } \\
1972 \\
1987 \\
\end{array}$ \\
\hline Agriculture and fishing & -4.1 & -5.1 & -6.0 & -11.7 & -5.2 & -6.3 \\
\hline Mineral Extraction & -4.6 & -1.6 & -9.4 & & -5.3 & -7.4 \\
\hline Manufacturing & & -2.8 & -7.3 & -7.3 & -4.0 & -5.6 \\
\hline Electricity, water and gas & & -1.8 & -10.4 & & -8.3 & \\
\hline Construction & -5.7 & -1.9 & -6.6 & -6.7 & -1.9 & -5.6 \\
\hline Trade and catering & -3.6 & -2.0 & -6.6 & -6.8 & -3.8 & -4.3 \\
\hline $\begin{array}{l}\text { Transport, storage and } \\
\text { communication }\end{array}$ & -3.7 & -2.3 & -6.6 & -5.6 & -3.2 & -7.6 \\
\hline $\begin{array}{l}\text { Banking, insurance and } \\
\text { commercial services }\end{array}$ & -8.3 & -2.9 & -6.3 & -5.6 & -3.4 & -5.8 \\
\hline Other services & -4.5 & -2.2 & -6.8 & -5.0 & -3.2 & -5.5 \\
\hline Total & -5.3 & -2.9 & -7.3 & -6.7 & -3.5 & -5.6 \\
\hline
\end{tabular}

Source: OECD (1989), (figures 1987)

* CBS/ROA (figures 1979 en 1985)

Table 22. Annual percentage changes in the proportion of active population with level-E education

\begin{tabular}{|c|c|c|c|c|c|c|}
\hline $\begin{array}{l}\text { eerste meting } \\
\text { tweede meting } \\
\end{array}$ & $\begin{array}{c}\text { The Netherlands* } \\
\begin{array}{c}1979 \\
1985 \\
\end{array}\end{array}$ & $\begin{array}{c}\text { (West) Germany } \\
1978 \\
1987 \\
\end{array}$ & $\begin{array}{l}\text { Japan } \\
1974 \\
1987 \\
\end{array}$ & $\begin{array}{c}\text { Sweden } \\
1971 \\
1987 \\
\end{array}$ & $\begin{array}{c}\text { United Kingdom } \\
1981 \\
1987 \\
\end{array}$ & $\begin{array}{c}\text { United States } \\
1972 \\
1987 \\
\end{array}$ \\
\hline Agriculture and fishing & & 9.9 & 4.0 & 7.2 & 2.4 & 7.5 \\
\hline Mineral Extraction & 2.9 & 2.4 & 5.6 & & 7.6 & 4.2 \\
\hline Manufacturing & & 6.9 & 3.7 & 6.7 & 4.7 & 5.8 \\
\hline Electricity, water and gas & & 1.7 & 3.6 & & 9.4 & \\
\hline Construction & 12.0 & 6.2 & 3.4 & 4.5 & 4.7 & 4.4 \\
\hline Trade and catering & 4.7 & 5.2 & 3.2 & 6.2 & 2.7 & 4.4 \\
\hline $\begin{array}{l}\text { Transport, storage and } \\
\text { communication }\end{array}$ & 12.3 & 5.1 & 2.8 & 9.0 & 0.3 & 6.9 \\
\hline $\begin{array}{l}\text { Banking, insurance and } \\
\text { commercial services }\end{array}$ & 4.4 & 3.1 & 4.0 & 5.3 & 3.6 & 3.7 \\
\hline Other services & 2.0 & 0.3 & 3.4 & 2.9 & 2.0 & 2.4 \\
\hline Total & 5.0 & 2.5 & 4.3 & 5.1 & 3.5 & 4.0 \\
\hline
\end{tabular}

Source: OECD (1989), (figures 1987)

* CBS/ROA (figures 1979 en 1985)

Table 21 shows the percentage annual change in the level-E educated portion of the active labour force, broken down by sector. The conclusion is that in all the countries examined the share of level-A people in the active labour force has declined. The decline appears to be 
greatest in Japan, followed by Sweden and the United States. The Netherlands hold an intermediary position. In the Netherlands, the sectors Banks and Insurance Companies, Business Services, and Construction and Installation Companies, show the steepest decline in the proportion of lower-educated.

Table 22 displays the percentage annual change in the level-E educated proportion of active workers. Apparently, the increase in this level of education has been greatest in Sweden, followed by the Netherlands.

Finally, table 23 surveys the annual changes in the shares of five educational levels in the potential labour force.

Table 23. Annual changes of the shares of education levels in the potential labour force

\begin{tabular}{|c|c|c|c|c|c|}
\hline & \multicolumn{5}{|c|}{ Level of education } \\
\hline & $\mathrm{A}$ & B & C & D & $\mathrm{E}$ \\
\hline $\begin{array}{l}\text { The Netherlands } \\
1979-1985\end{array}$ & -3.20 & 2.78 & & 3.90 & 3.99 \\
\hline $\begin{array}{l}\text { United States } \\
1972-1988\end{array}$ & -2.83 & 0.51 & & 2.23 & 3.34 \\
\hline $\begin{array}{l}\text { Japan } \\
\text { 1974-1987 }\end{array}$ & -2.76 & 1.54 & & & 3.55 \\
\hline $\begin{array}{l}\text { (West) Germany } \\
1978-1987\end{array}$ & -2.16 & -3.75 & 0.90 & 4.20 & 2.75 \\
\hline $\begin{array}{l}\text { Sweden } \\
1971-1987\end{array}$ & -2.71 & 1.86 & 5.31 & 7.08 & 5.60 \\
\hline
\end{tabular}

Source: OECD (1989)

CBS/ROA

Evidently, the share of the higher vocationally educated is growing less fast in the Netherlands than in (West) Germany and Sweden. Sweden leads in terms of increasing proportion of university graduates, with the Netherlands and Japan as runners-up.

Forecasts of total employment and employment for technicians have been received from six out of the seven countries involved in the investigation. Regrettably, the forecasts for technicians are not quite comparable. For the Netherlands and the United Kingdom they refer to employment for the technically schooled; for the United States, Sweden and France to the development of employment for technical occupations. The figures for (West) Germany refer to the Research and Development sector. 
$-30-$

Table 24. Forecasts of employment for technicians and total employment, by level of education, 1982/8-2000

\begin{tabular}{|c|c|c|c|c|c|}
\hline & Occupational group & $\begin{array}{c}\% \text {-change } 1982 / 8- \\
2000\end{array}$ & low & $\begin{array}{c}\text { Average } \\
\text { level of education }\end{array}$ & high \\
\hline The Netherlands & $\begin{array}{l}\text { Technicians } \\
\text { Total employment }\end{array}$ & $\begin{array}{l}19.6 \\
20.4\end{array}$ & $\begin{array}{r}-4.8 \\
-10.6\end{array}$ & $\begin{array}{l}36.2 \\
34.9\end{array}$ & $\begin{array}{l}37.3 \\
61.4\end{array}$ \\
\hline United States & $\begin{array}{l}\text { Technicians } \\
\text { Total employment }\end{array}$ & $\begin{array}{l}32 \\
15\end{array}$ & $\begin{array}{l}29 \\
40\end{array}$ & $\begin{array}{l}36 \\
21\end{array}$ & $\begin{array}{l}32 \\
23\end{array}$ \\
\hline (West) Germany & $\begin{array}{l}\text { Technicians } \\
\text { Total employment }\end{array}$ & $\begin{array}{l}40 \\
-1.1\end{array}$ & $\begin{array}{l}-66.8 \\
-36.7\end{array}$ & $\begin{array}{r}49.6 \\
8.6\end{array}$ & $\begin{array}{l}64.4 \\
71.1\end{array}$ \\
\hline Sweden & $\begin{array}{l}\text { Technicians } \\
\text { Total employment }\end{array}$ & $\begin{array}{l}28 \\
12\end{array}$ & $-6 \overline{1.8}$ & $\overline{55.1}$ & $\overline{60.8}$ \\
\hline France & $\begin{array}{l}\text { Technicians } \\
\text { Total employment }\end{array}$ & $\begin{array}{r}18.8 \\
2.4\end{array}$ & $\begin{array}{l}-- \\
--\end{array}$ & $\begin{array}{l}-- \\
--\end{array}$ & $\overline{-}$ \\
\hline United Kingdom & $\begin{array}{l}\text { Technicians } \\
\text { Total employment }\end{array}$ & $\begin{array}{r}36.0 \\
8.4 \\
\end{array}$ & $+\overline{2.3}$ & $\begin{array}{l}38.5 \\
28.0 \\
\end{array}$ & $\begin{array}{l}46.1 \\
52.1\end{array}$ \\
\hline
\end{tabular}

Source: The Netherlands (1985-2000): CPB, WD25, 1989, p. 14

United States (1988-2000): BLS, MLR, 1989 (11), p. 62

(West) Germany (1982-2000): IÁB, BÁB, 1986 (95)

Sweden (1985-2005): SCB, TOP, 1990, p. 168

France (1986-2000): BIPE, CALIFE, 1989, p. 5

United Kingdom (1988-2000): IER, Wilson (1990), p. 36

Legend: $--=$ unknown

Despite the poor comparability of the figures presented, two important conclusions are warranted: for all countries except the Netherlands, employment for technicians is expected to grow faster than total employment, and the growth will be largely accounted for by the groups with a secondary or higher education-level.

\subsection{Educational data}

\subsubsection{Participation in higher education}

Table 25 pictures percentage participation in higher education.

Table 25. Participation in higher education as a percentage of the number of persons betweed the ages of 20 and 24

\begin{tabular}{|c|c|c|c|c|}
\hline & $\begin{array}{c}1970 \\
\% \\
\end{array}$ & $\begin{array}{c}1975 \\
\% \\
\end{array}$ & $\begin{array}{c}1980 \\
\%\end{array}$ & $\begin{array}{c}1985 \\
\%\end{array}$ \\
\hline The Netherlands & 20 & 25 & 30 & 32 \\
\hline United States & 49 & 57 & 56 & 57 \\
\hline Japan & 17 & 25 & 31 & 29 \\
\hline France & 20 & 25 & 26 & 30 \\
\hline (West) Germany & 13 & 25 & 26 & 30 \\
\hline United Kingdom & 14 & 19 & 20 & 22 \\
\hline Belgium & 18 & 23 & 26 & 31 \\
\hline Denmark & 18 & 29 & 29 & 29 \\
\hline Sweden & 21 & 29 & 37 & 37 \\
\hline Switzerland & 10 & 14 & 18 & 22 \\
\hline
\end{tabular}

Source: UNESCO 
The figures confirm that in the years from 1970 to 1985 , participation in higher education extended greatly in all countries investigated, the Netherlands ranking third among the selected countries.

\subsubsection{Average level of education}

The average level of education (ALE) of a country's population can be taken as an indicator of the societal and scientific breeding ground for technological innovation. This indicator has been composed by allotting weights to the various levels of education. After multiplication and adding one figure emerges that counts as a country's ALE (table 26). Of this indicator, time series can in principle be drawn up.

Table 26. Average level of education of potential labour force, 1988

\begin{tabular}{lc}
\hline & Indicator \\
\hline The Netherlands & 1.82 \\
United States & 2.72 \\
Japan & 2.15 \\
(West) Germany & 2.39 \\
United Kingdom & 2.62 \\
Sweden & 2.28 \\
\hline
\end{tabular}

Source: OECD/ROA

The relatively low level of education of the Netherlands strikes the eye. It can be explained in part by the low proportion of higher educated women. On checking, we found that the information for the Netherlands derives from the Labour-Force Survey 1987, whose educational data are considered unreliable by the CBS itself.

\subsubsection{Premature schoolleavers}

Table 27. Premature schoolleavers as a percentage of the total number of schoolleavers*

\begin{tabular}{ll}
\hline & $\%$ \\
\hline The Netherlands & 17 \\
France & 13 \\
United Kingdom & 15 \\
\hline
\end{tabular}

Source: OECD (1984)

* The figures to the second half of the 1970 s

So far, reliable, internationally comparable figures about premature schoolleavers are few and far between. Several national publications admittedly mention the proportion of uncertified or 
unskilled members of the labour force, but internationally, published information is scarce. Table 27 reproduces the proportions of early schoolleavers as mentioned in Lowe (1990). The figures refer to the second half of the 1970s. So far we have not been able to trace the precise years to which the figures refer.

Although a comparison is rather premature, the conclusion is warranted that the proportion of premature schoolleavers in the Netherlands is relatively high.

\subsubsection{Education and training of young people}

The British department of Education and Science, quoted earlier, has established the participation of 18-year-olds in education and training as a percentage of the total number of 18-year-olds in 1986. Table 28 shows that (West) Germany and the Netherlands score highest at 80 and 72 per cent, respectively. Almost half of all (West-)German youngsters at the age of 18 are following a part-time course. For Japan, Sweden, the United States and France the corresponding percentages are very low: between 2 and 4 . The 18-year-olds in Belgium and the Netherlands appear to be the most frequent followers of full-time education: 64 and 61 per cent, respectively.

Table 28. Participation of 18-year-olds in education and training, 1986, in percentages

\begin{tabular}{|c|c|c|c|}
\hline & $\begin{array}{c}\text { full-time } \\
\%\end{array}$ & $\begin{array}{c}\text { part-time } \\
\%\end{array}$ & $\begin{array}{c}\text { total } \\
\%\end{array}$ \\
\hline The Netherlands & 61 & 11 & 72 \\
\hline United States & 55 & 3 & 59 \\
\hline Japan & 50 & 2 & 51 \\
\hline France & 52 & 4 & 56 \\
\hline (West) Germany* & 33 & 47 & 80 \\
\hline United Kingdom & 19 & 24 & 42 \\
\hline Belgium & 64 & 5 & 69 \\
\hline Denmark & 57 & 10 & 67 \\
\hline Sweden & 52 & 4 & 55 \\
\hline Australia & 25 & 23 & 47 \\
\hline Canada & 53 & -- & 53 \\
\hline Italy** & 41 & 15 & 56 \\
\hline Spain & 44 & -- & 44 \\
\hline
\end{tabular}

Source: Department of Education and Science (DES), 1990

* figures 1987

* figures 1982 


\subsubsection{Quality of education}

Under the auspices of The International Association for the Evaluation of Educational Achievement (IEA), the quality of education is being internationally investigated and compared. In the recent past, the teaching of mathematics and physical sciences and the importance of computers to teaching have been objects of study.

\section{Mathematics}

From 1980 to 1982, data were collected in 20 countries for the Second International Mathematics Study. As with a first project in the 1960s, the Netherlands only participated in the crosssection inquiry among 13-year-olds. The second part of this IEA project concerned students at the final stage of secondary education with mathematics as a major subject (at least 5 hours a week).

Table 29. Average score of 13-year-old students in international comparative mathematics examination, 1982

\begin{tabular}{lcccccccc}
\hline & \multicolumn{2}{c}{ Arithmetics } & \multicolumn{2}{c}{ Algebra } & \multicolumn{2}{c}{ Geometry } & \multicolumn{3}{c}{ discribtive statistics } \\
& 1964 & 1982 & 1964 & 1982 & 1964 & 1982 & 1964 & 1982 \\
\hline The Netherlands & 60 & 54 & 34 & 53 & 36 & 46 & 56 & 66 \\
Japan & 64 & 60 & 55 & 61 & 68 & 69 & 77 & 73 \\
France & 61 & 60 & 30 & 60 & 51 & 37 & 55 & 58 \\
England/Wales & 53 & 44 & 48 & 41 & 50 & 42 & 62 & 52 \\
United States & 54 & 50 & 39 & 42 & 37 & 34 & 56 & 54 \\
Sweden & 42 & 35 & 26 & 33 & 34 & 38 & 50 & 51 \\
\hline
\end{tabular}

Source: Robitaille \& Garden (1989)

The 13-year-old students participating in the inquiry were given questions to answer about a set of items from four areas of mathematics. Table 29 gives the average scores of the students from the various countries.

Japanese students appear to have obtained the highest average scores on all subjects. The Dutch students are runners-up in most cases. That the Dutch students lost out on arithmetics in favour of the other three mathematic elements is undoubtedly due to the changes recently carried through in the teaching of mathematics.

\section{Physical sciences}

In 1970, 19 members of the IEA compared learning performances in physical sciences. The 
exercise was repeated in the 1983-1986 period. Students from three age brackets (and of various levels of education) had to complete a questionnaire with multiple-choice questions about biology, chemics, physics and geology. For financial reasons, both in 1970 and between 1983 and 1986 the Netherlands only took part in the inquiries among the 14-year-olds. Table 30 presents the results of the most recent inquiry. The table ranks the participating countries by their learning performances on several levels. To be complete, we present here the data of all participating countries.

Table 30. Ranking of countries by learning performances of students in physical sciences, by age brackets, 1986

\begin{tabular}{|c|c|c|c|c|c|}
\hline & \multirow[t]{2}{*}{ 10-year-olds } & \multirow[t]{2}{*}{ 14-year-olds } & \multicolumn{3}{|c|}{ 18-year-olds students in: } \\
\hline & & & Biology & Chemistry & Physics \\
\hline Hungary & 5 & 1 & 3 & 5 & 3 \\
\hline Japan & 1 & 2 & 10 & 4 & 4 \\
\hline The Netherlands & -- & 3 & -- & -- & -- \\
\hline Canada & 6 & 4 & 11 & 12 & 11 \\
\hline Finland & 3 & 5 & 7 & 13 & 12 \\
\hline Sweden & 4 & 6 & 8 & 9 & 10 \\
\hline Korea & 1 & 7 & -- & -- & -- \\
\hline Poland & 11 & 7 & 4 & 7 & 7 \\
\hline Norway & 10 & 9 & 6 & 8 & 6 \\
\hline Australia & 9 & 10 & 9 & 6 & 8 \\
\hline Italy & 7 & 11 & 12 & 10 & 13 \\
\hline United Kingdom & 12 & 11 & 2 & 2 & 2 \\
\hline Singapore & 13 & 14 & 1 & 3 & 5 \\
\hline Thailand & -- & 14 & -- & -- & -- \\
\hline United States & 8 & 14 & 13 & 11 & 9 \\
\hline Hong Kong & 13 & 16 & 5 & 1 & 1 \\
\hline Philipean & 15 & 17 & -- & -- & -- \\
\hline $\begin{array}{l}\text { Total number of } \\
\text { countries }\end{array}$ & 15 & 17 & 13 & 13 & 13 \\
\hline
\end{tabular}

Source: IEA (1988)

Legend: $--=\ldots . .$.

The following conclusions can be drawn from this table.

- Dutch 14-year-old students scored third, after Hungary and Japan, on a test of $\mathbf{3 0}$ questions of physical science.

- The United States ended up last among the participating developing countries.

\subsubsection{Computers in education}

In 1989, in the framework of the first stage of a longitudinal IEA study of computers in 
education (COMPED), data were collected on the use of computers in primary and secondary education in 22 countries.

The most important research questions referred to the availability and use of hardware and software, the problems encountered in the introduction of computers into schools and education, and the attitude of students to computers. There appears to have been achieved hardly any integration of the computer in existing subject areas, mostly for lack of high-grade software and well trained teachers.

Table 31 reproduces the initial results of the investigation into the first stage of secondary education. The table shows clearly that the United States had started a few years earlier with the introduction of computers into education than the other three countries. Japan is somewhat in arrear.

Table 31. Median number of computers used in secondary schools with computers, 1989

\begin{tabular}{lcccc}
\hline & \multicolumn{2}{c}{ country } \\
Year** & $\begin{array}{c}\text { The Netherlands } \\
\%\end{array}$ & $\begin{array}{c}\text { United States } \\
\%\end{array}$ & $\begin{array}{c}\text { Japan } \\
\%\end{array}$ & $\begin{array}{c}\text { France } \\
\%\end{array}$ \\
\hline 1985 & 8 & 12 & 0 & 7 \\
1986 & 8 & 15 & 1 & 9 \\
1987 & 11 & 20 & 1 & 10 \\
1988 & 13 & 23 & 5 & 12 \\
1989 & 18 & 30 & 4 & 15 \\
1990 & 19 & 33 & 11 & 17 \\
$\%$ schools with computers 1989 & 98 & & & 99 \\
\hline
\end{tabular}

* Second level, first stage amount.

Source: Plomp and Pelgrum (1990)

From complementary analyses carried out for the present investigation, the role of the computer appears quite different in French and Japanese teaching from that in the Netherlands and the United States (See table 32). Especially in general technological and mathematical education, computers are noticeably more popular in France and Japan. 
Table 32. Subject areas in which computers are used most, in percentages

\begin{tabular}{|c|c|c|c|c|}
\hline \multirow[b]{2}{*}{$\begin{array}{l}\text { Subject area in which } \\
\text { computers are used most }\end{array}$} & \multicolumn{4}{|c|}{ Country } \\
\hline & $\begin{array}{c}\text { The Netherlands } \\
\%\end{array}$ & $\begin{array}{c}\text { United States } \\
\% \\
\end{array}$ & $\begin{array}{c}\text { Japan } \\
\%\end{array}$ & $\begin{array}{c}\text { France } \\
\%\end{array}$ \\
\hline Special course & 91 & 52 & 32 & 10 \\
\hline Mathematic & 1 & 8 & 23 & 13 \\
\hline Physics & 1 & 4 & 14 & 2 \\
\hline Native language & 1 & 7 & 0 & 2 \\
\hline Foreign language & 0 & 0 & 2 & 1 \\
\hline Creative subjects & 0 & 0 & 0 & 0 \\
\hline Social subjects & 0 & 1 & 1 & 1 \\
\hline Commercial subjects & 1 & 4 & 0 & 1 \\
\hline Technology, general & 0 & 0 & 28 & 54 \\
\hline Technology, specific & 1 & 1 & 0 & 5 \\
\hline Economie & 0 & 0 & 0 & 1 \\
\hline Informal instruction & 0 & 1 & 0 & 7 \\
\hline
\end{tabular}

Source: Plomp and Pelgrum (1990)

\subsubsection{Expenditure on education}

Table 33. Governement expenditure on education in percentages of GNP

\begin{tabular}{lcccc}
\hline & $\begin{array}{c}1970 \\
\%\end{array}$ & $\begin{array}{c}1975 \\
\%\end{array}$ & $\begin{array}{c}1980 \\
\%\end{array}$ & $\begin{array}{c}1985 \\
\%\end{array}$ \\
\hline The Netherlands & 5.8 & 6.8 & 6.9 & 6.1 \\
United States & 5.6 & 5.7 & -- & -- \\
Japan & 2.9 & 3.9 & 3.9 & 4.8 \\
France & 3.1 & 4.6 & 4.7 & 5.3 \\
(West) Germany & 2.5 & 4.1 & 4.1 & 4.1 \\
United Kingdom & 4.6 & 6.0 & 5.3 & 5.0 \\
Belgium & 4.2 & 5.7 & 6.9 & 6.1 \\
Denmark & 5.3 & 6.8 & 6.1 & - \\
Sweden & 6.3 & 6.4 & 7.8 & 6.9 \\
Swiss & 2.9 & 4.2 & 4.5 & 4.4 \\
\hline
\end{tabular}

Source: UNESCO

Table 33 indicates the level of public expenditure on education as a percentage of GNP. From the table, the Netherlands spent the second-highest proportion - after Sweden - of GNP on education, both in 1970 and in 1985. However, the spending quota grew little in the Netherlands between 1970 and 1985, less than in the other countries. After 1980, in the Netherlands and Sweden the proportion of GNP spent on education dropped sharply. Shifts in the composition of spending on education may suggest some interesting changes of policy. In many Western OECD countries, for example, the amounts spent on distant and adult education have greatly 
Table 32. Subject areas in which computers are used most, in percentages

\begin{tabular}{lcccc}
\hline & \multicolumn{2}{c}{ Country } & \\
$\begin{array}{l}\text { Subject area in which } \\
\text { computers are used most }\end{array}$ & $\begin{array}{c}\text { The } \\
\text { \% }\end{array}$ & $\begin{array}{c}\text { United States } \\
\%\end{array}$ & $\begin{array}{c}\text { Japan } \\
\%\end{array}$ & $\begin{array}{c}\text { France } \\
\%\end{array}$ \\
\hline Special course & 91 & 52 & 32 & 10 \\
Mathematic & 1 & 8 & 23 & 13 \\
Physics & 1 & 4 & 14 & 2 \\
Native language & 1 & 7 & 0 & 2 \\
Foreign language & 0 & 0 & 2 & 1 \\
Creative subjects & 0 & 0 & 0 & 0 \\
Social subjects & 0 & 1 & 1 & 1 \\
Commercial subjects & 1 & 0 & 1 \\
Technology, general & 0 & 4 & 28 & 54 \\
Technology, specific & 1 & 0 & 0 & 5 \\
Economie & 0 & 1 & 0 & 1 \\
Informal instruction & 0 & 0 & 0 & 7 \\
\hline
\end{tabular}

Source: Plomp and Pelgrum (1990)

\subsubsection{Expenditure on education}

Table 33. Governement expenditure on education in percentages of GNP

\begin{tabular}{lcccc}
\hline & $\begin{array}{c}1970 \\
\%\end{array}$ & $\begin{array}{c}1975 \\
\%\end{array}$ & $\begin{array}{c}1980 \\
\%\end{array}$ & $\begin{array}{c}1985 \\
\%\end{array}$ \\
\hline The Netherlands & 5.8 & 6.8 & 6.9 & 6.1 \\
United States & 5.6 & 5.7 & -- & -- \\
Japan & 2.9 & 3.9 & 3.9 & 4.8 \\
France & 3.1 & 4.6 & 4.7 & 5.3 \\
(West) Germany & 2.5 & 4.1 & 4.1 & 4.1 \\
United Kingdom & 4.6 & 6.0 & 5.3 & 5.0 \\
Belgium & 4.2 & 5.7 & 6.9 & 6.1 \\
Denmark & 5.3 & 6.8 & 6.1 & -- \\
Sweden & 6.3 & 6.4 & 7.8 & 6.9 \\
Switzerland & 2.9 & 4.2 & 4.5 & 4.4 \\
\hline
\end{tabular}

Source: UNESCO

Table 33 indicates the level of public expenditure on education as a percentage of GNP. From the table, the Netherlands spent the second-highest proportion - after Sweden - of GNP on education, both in 1970 and in 1985. However, the spending quota grew little in the Netherlands between 1970 and 1985, less than in the other countries. After 1980, in the Netherlands and Sweden the proportion of GNP spent on education dropped sharply. Shifts in the composition of spending on education may suggest some interesting changes of policy. In many Western OECD countries, for example, the amounts spent on distant and adult education have greatly 
increased of late years.

\subsection{Information on training}

\section{Participation in training}

In 1990, the European Centre for the Development of Vocational Training (CEDEFOP) made a first timid attempt at gathering and comparing data about education and vocational training courses in four West-European countries. That was done in four separate monographs for the participating countries, containing data deriving from official agencies. The comparison will be repeated and extended in the coming years.

Table 34. Participation in training activities, by occupational classes, 1987-88, in percentages

\begin{tabular}{|c|c|c|c|c|c|}
\hline & Management & Administrative & Technicical & Skilled workers & Unskilled \\
\hline The Netherlands & 50 & 26 & 40 & 10 & 5 \\
\hline (West) Germany & 65 & 38 & 40 & 10 & 3 \\
\hline France & 60 & 27 & 48 & 28 & 16 \\
\hline United Kingdom & 40 & 38 & 46 & 27 & 20 \\
\hline
\end{tabular}

Source: CEDEFOP Flash 90/1

Table 34 reviews the participation in training activities by five occupational categories. The conclusion from this table is that the Netherlands' participation in training activities for most occupational categories is relatively poor.

Financing of training activities

Table 35. Sources for the financing of training activities, in percentages

\begin{tabular}{lccc} 
& $\begin{array}{c}\text { Public sector } \\
\%\end{array}$ & $\begin{array}{c}\text { Private enterprise } \\
\%\end{array}$ & $\begin{array}{c}\text { Employee's } \\
\%\end{array}$ \\
\hline The Netherlands & 39 & $50^{*}$ & 11 \\
(West) Germany & 25 & $50^{* *}$ & 25 \\
France & 53 & 43 & 4 \\
United Kingdom *** & 20 & 51 & 29 \\
\hline
\end{tabular}

Source: CEDEFOP Flash 90/1

* Includes also some public sources

** Does not contain all forms of on-the-job training

*** Expenditures on Youth Training System are included in continuing training

In the CEDEFOP-inquiry mentioned earlier, a comparison was also made of the financing of training activities in various countries. Table 35 was drawn up by CEDEFOP from official 
sources as far as public expenditure was concerned, and from estimates based on empirical research as far as spending by private enterprise was at stake. With the exception of France, in most countries private enterprise is the greatest sponsor of training activities. Another striking fact is that in Great Britain the public sector spends relatively little on training. CEDEFOP moreover remarks that in the past few years, private expenditure on training has increased much more than public expenditure, especially in France and the Netherlands.

\subsection{Mobilisation of $R \& D$ potential}

Table 36. R\&D-staff related to the scientific and technical (S\&C) potential

\begin{tabular}{|c|c|c|c|c|c|}
\hline & & & S\&T staff in R\&D & S\&T potential & $\%$ \\
\hline \multirow[t]{3}{*}{ The Netherlands } & $(' 85)$ & scientists \& engineers & 33,620 & 972,300 & 3.46 \\
\hline & & technicians & 27,280 & $2,128,000$ & 1.28 \\
\hline & & total & 61,400 & $3,100,300$ & 1.98 \\
\hline \multirow[t]{3}{*}{ United States } & $\left({ }^{\prime} 86\right.$ en '82)* & scientists \& engineers & 787,400 & $3,431,800$ & 22.94 \\
\hline & & technicians & -- & -- & -- \\
\hline & & total & -- & -- & -- \\
\hline \multirow[t]{3}{*}{ Japan } & $(' 86$ en '82)* & scientists \& engineers & 575,292 & $7,046,000$ & 8.16 \\
\hline & & technicians & 101,861 & $30,004,000$ & 0.34 \\
\hline & & total & 677,153 & $37,050,000$ & 1.83 \\
\hline \multirow[t]{3}{*}{ France } & $(' 85$ en '75)* & scientists \& engineers & 102,300 & $1,251,610$ & 8.17 \\
\hline & & technicians & 170,700 & -- & -- \\
\hline & & total & 273,000 & -- & -- \\
\hline \multirow[t]{3}{*}{ (West) Germany } & $\left({ }^{\prime} 83\right.$ en '80)* & scientists \& engineers & 133,114 & $2,278,000$ & 5.84 \\
\hline & & technicians & 119,617 & $6,096,000$ & 1.96 \\
\hline & & total & 252,731 & $8,374,000$ & 3.02 \\
\hline \multirow[t]{3}{*}{ Sweden } & ('85 en '79) & scientists \& engineers & 21,202 & 335,900 & 6.31 \\
\hline & & technicians & 29,001 & $1,842,500$ & 1.57 \\
\hline & & total & 50,203 & $2,178,400$ & 2.30 \\
\hline
\end{tabular}

* The years refer respectively to column 1 and 2 Legend: $--=$ unknown

Source: UNESCO/ROA

An important indicator of the R\&D infrastructure is the share of R\&D staff in the total labour force. One way to construct an indicator of the technological potential of the labour force is to relate the number of persons actually occupied in R\&D to the number of persons that could potentially be occupied in R\&D ('the scientific and technical potential'), that is, the number of economically active persons who are qualified to be employed as scientists, engineers or technicians. This indicator can be calculated for a number of countries from UNESCO data. 
$-39-$

A striking feature is the high proportion of the American R\&D-potential of scientists and engineers actually employed in R\&D. Another fact to be rememberd is that in relative terms, technicians end up far less frequently in R\&D than scientists and engineers. Of the Dutch R\&Dpotential a relatively small portion indeed finds employ in R\&D. These figures could be updated regularly. 


\section{INTERNATIONAL DEVELOPMENTS}

Although the supply of comparable figures on schooling and labour is still limited, the conclusion is warranted that national and international organisations show a growing interest in this subject. The following initiatives may be relevant to the follow-up to METING:

1. The OECD recently made a start with the organisation of an annual survey that is to produce comparable data on various aspects of education in the member states. That project, the International Educational Indicators Project (INES Project), is being prepared for the Centre for Educational Research and Innovation (CERI) of the OECD by five networks. Network 1 is directed entirely to the development of indicators describing participation and moving on in the educational system. One proposed indicator refers to the number of graduates of technical and scientific programmes. One theme of Network 2 is the output of the educational system, a theme that by a decision made early in 1990 was narrowed down to 'education and the destination on the labour market'. Several labour-market indicators have been considered for the planned survey (labour-market position, occupation, sector, income, etc.); finally, the following six were formulated:

1. Position on the labour market;

2. Division of occupations of employed and unemployed persons;

3. Labour-market status and training of schoolleavers;

4. Participation of adults in education and training;

5. Income/wage of adults;

6. Accordance between training and occupation.

Work is in hand to define these indicators and make them operational. In February 1991 decisions will be made about the final organisation of the survey.

2. In the coming years, the IEA will repeat its internationally comparative investigations into the teaching of mathematics and physical sciences and the role of computers in education. For financial reasons, the Netherlands has taken only a limited part in these investigations in the past. As a result, some data potentially relevant for METING are lacking.

3. The CEDEFOP has also started to collect internationally comparable data on training and vocational courses. National research institutes have undertaken separate studies for the participating countries. The results will afterwards be summarised in so-called 'Flashes'. In the autumn of 1990 a conference will be held where the co-ordination of the inquiries will be on the agenda. 
$-41-$

4. Under the auspices of the EC work has been in progress since 1 December 1987 on the PETRA project. PETRA stands for 'Partnerships in European Training'; the project is carried out in the context of the European action programme 'Vocational Training of Young People and their Preparation for Adult Life'. The ITS in Nijmegen is charged with the researchtechnical support of the institutions participating in PETRA. PETRA proceeds along five separate lines, of which line 2, 'Approaches to Monitoring Participation Trends in Vocational Training' is the most important for METING. In the framework of this project, internationally comparative data on vocational education were gathered in the spring of 1990 . 


\section{LITERATURE}

British Department of Education and Science (DES), (1990), International Statistical Comparisons of the Education and Training of 16 to 18 Year Olds, Statistical Bulletin 1/90, London.

Bund-Länder-Kommission für Bildungsplanung und Forschungsförderung (BLK), (1987), Künftige Perspektiven von Absolventen der Beruflichen Bildung im Beschäftigungssytem, Materialien zur Bildungsplanung Heft 15, Bonn.

Bund-Länder-Kommission für Bildungsplanung und Forschungsförderung (BLK),(1989), Gesamtbetrachtung $z u$ den Beschäftigungsperspektiven von Absolventen des Bildungssystems, Materialien zur Bildungsplanung Heft 18, Bonn.

Bureau d'Informations et de Previsions Economiques (BIPE), (J.P.Sicard e.a), (1987), Modele CALIFE, Systeme d'Observation et de Prevision des Emploi et des Formations à moyen terme, Issy-les-Moulineaux.

Bureau of Labor Statistics (BLS), (1989), in: Monthly Labor Review no. 11, 1989, Washington D.C.

Centraal Planbureau (CPB), (1989), (R. van Opstal), Werkdocument 25 (WD25), Arbeidsaanbod en werkgelegenheid naar 11 opleidingscategorieën 1985-2000; een actualisering van werkdocument 17, Den Haag.

Centre Européen pour le Développement de la Formation Professionnelle (CEDEFOP), (1990), Flash Special 1/90, Berlin.

Commission of the European Communities, (1990), The Labour Market for Information Technology, Social Europe 1990/1, Brussels

Grip A. de (1987), Onderwijs en arbeidsmarkt: scholingsdiscrepanties, Amsterdam.

Grip A. de, J.A.M. Heijke (1988), Labour Market Indicators: an inventory, ROA-W-1988/1E, Maastricht.

Grip, A. de, W.J. Nusselder, (1989), Technology Indicators Referring to Education and Labour, ROA-R-1989/4E, Maastricht.

Institut für Arbeitsmarkt- und Berufsforschung (IAB), (1990), Beitrage zur Arbeitsmarkt und Berufsforschung 95, 1986, Nürnberg.

Institute for Employment Research (IER), (R.A.Wilson e.a.), (1990), Projecting the Labour Market for the Highly Qualified, University of Warwick, Colchester.

International Labour Organization (ILO) (1982-1988), Yearbook of Labour Statistics, Geneva.

International Organisation for the Evaluation of Educational Achievement (IEA), (1988), Science Achievement in seventeen countries, A Preliminary Report, Oxford.

Kodama, F., F. Niwa, (1987), Structure Analysis of the Japanese Science Indicator System and its Evaluation, in: The Journal of Science Policy and Research Management, Vol. 2, no. 2, pp.173-183.

Lowe, J., (1990), Educational trends and prospects in OECD countries, A report prepared for 
the Inquiry Commission of the German Federal Parliament, Bonn.

Ministerie van Onderwijs en Wetenschappen, (1990), Skill-prognoses 1990, Den Haag.

Ministerie van Economische Zaken, (1988), METING Voorstel voor een gegevensbank van Technologie Indicatoren voor Algemeen Technologie Beleid, Den Haag.

Ministerie van Sociale Zaken en Werkgelegenheid, (1989), Rapportage Arbeidsmarkt 1989, Den Haag.

Organisation for Economic Co-operation and Development (OECD), (1988), Quarterly Labour Force Statistics, Paris.

Organisation for Economic Co-operation and Development (OECD), (1989), Employment Outlook 1989, Paris.

Plomp, Tj., W.J. Pelgrum (1990), Introduction of Computers in Education: state of the art in eight countries, Enschede. (Paper presented at EURIT 90, the European Conference on Technology and Education, Herning, Denmark, 1990).

Prognos AG, research for: Institut für Arbeitsmarkt- und Berufsforschung (IAB), (1990),- Die Arbeitsmärkte im EG-Binnenmarkt bis zum Jahr 2000, Beitrage zur Arbeitsmarkt- undBerufsforschung 138.1, Nürnberg.

Robitaille, D.F., R.A. Garden, (1989), The IEA Study of Mathematics II: Contexts and Outcomes of School Mathematics, Oxford.

Statistical Office of the European Communities (Eurostat), (1989), Labour Force Survey (not published statistics), Luxembourg.

Statistiska Centralbyrån (SCB), (1990), Trender och Prognoser, med sikte på 2015, Stockholm.

United Nations Educational Scientific and Cultural Organization (UNESCO), (1984-1988), Statistical Yearbook, Paris.

Weiss, R., (1990), Die 26 Mrd.-Investition - Kosten und Strukturen betrieblicher Weiterbildung, Deutscher Instituts-Verlag, Köln.

Wijst, T. van der, (1987 I), Developments in the age structure of the labour force by industry and by occupation: an international comparison for some selected countries of the Economic Commission for Europe, Working Paper no.74, The Hague.

Wijst, T. van der, (1987 2), Recent and future changes in the age structure of the Dutch Working force, Working Paper no. 75, The Hague. 


\section{CONSULTED AUTHORITIES}

\section{International}

OECD/CERI Centre for Educational Research and Innovation (Parijs)

OECD/CAD Central Analysis Division (Parijs)

OECD/DSTI Directorate for Science, Technology and Industry (Parijs)

OECD/SME Directorate Social Affairs, Manpower and Education (Parijs)

ILO/ Department Vocational Training (Genève)

UNESCO (Parijs)

EG Task Force Human Resources, Education, Training and Youth (Brussel)

EG Directorate-General for Science, Research and Development (Brussel)

Eurostat Education and Training (Luxemburg)

European Institute for Vocational Training (Parijs)

IEA The International Association for the Evaluation of Educational Achievement (Den Haag)

CEDEFOP Centre Europeén pour le Développement de la Formation Professionelle (Berlijn)

\section{France}

BIPE Bureau d'Informations et de Prévisions Economiques (Neuilly)

CEREO Centre d'Etudes et de Recherches sur les Qualifications (Parijs)

INSEE Institut National de la Statistique et des Etudes Economiques (Parijs)

Ministère des Affaires sociales et de l'Emploi (Parijs)

Délégation à la formation professionelle

Ministère de l'Education Nationale (Parijs)

Direction des Affaires Générales, Internationales et de la Coöpération

Direction des Etudes et de la Prospective

Japan

National Institute of Employment and Vocational Research (Tokio)

National Institute for Educational Research (Tokio)

Ministry of Education (Tokio)

Japanse delegatie bij OECD (Parijs) 


\section{(West) Germany}

St BA Statistisches Bundesamt (Wiesbaden)

WBS Wischenschaftszentrum Berlin für Sozialforschung (Berlijn)

BIBB Bundesinstitut für Berufsbildung (Berlijn)

IAB Institut für Arbeitsmarkt- und Berufsforschung (Neurenberg)

Bundesminister für Bildung und Wissenschaft (Bonn)

Universität von Paderborn (Paderborn)

DIW Institut der Deutschen Wirtschaft (Köln)

Deutscher Bundestag (Bonn)

Enquete Kommission Zukünftige Bildungspolitik - Bildung 2000

BLK Bund-Länder Kommission für Bildungsplanung und Forschungsförderung (Bonn)

\section{United Kingdom}

DE Department of Employment (Statistical Branch) (Londen)

DES Department of Education and Science, (Statistical Branch) (Londen)

HMSO HM. Stationery Office (Londen)

USR Universities Statistical Record (Cheltenham)

The Training Agency (Sheffield)

ESRC-Data Archive (University of Essex) (Colchester)

IMS Institute of Manpower Studies (Brighton)

IER Institute for Employment Research/University of Warwick (Coventry)

VEC Vocational and Educational Centre/University of Warwick (Coventry)

University of Lancaster - Department of Economics (Lancaster)

\section{Sweden}

SCB Statistiska Central byrån (Bureau of Statistics) (Stockholm)

- Unit of Education and Culture

- Unit of Labour Market Statistics

- Forecasting Institute

Ministry of Education (Division of Research/Statistics) (Stockholm)

Arbetslivcentrum (Stockholm)

Gothenborg University/Education and Educational Research (Mölndal)

Swedish National Board of Education (Stockholm)

Stockholm School of Economics (Stockholm) 


\section{United States}

US Department of Education (Office of Research) (Washington)

US Department of Labor (Washington)

- Bureau of International Labor Affairs

- Bureau of Labor Statistics (BLS)

- National Commission on Employment Policy

US Department of Commerce (Washington)

- Bureau of the Census

- Bureau of Economic Analysis

American Council on Education (Washington)

American Society for Training and Development (Alexandria)

National Centre for Research in Vocational Training (Columbus)

Columbia University Conservation of Human Resources (New York) 